52 UC-NRLF

355

$M 29$

WDOK OF RRUIS

TIRSI SMRILS. 


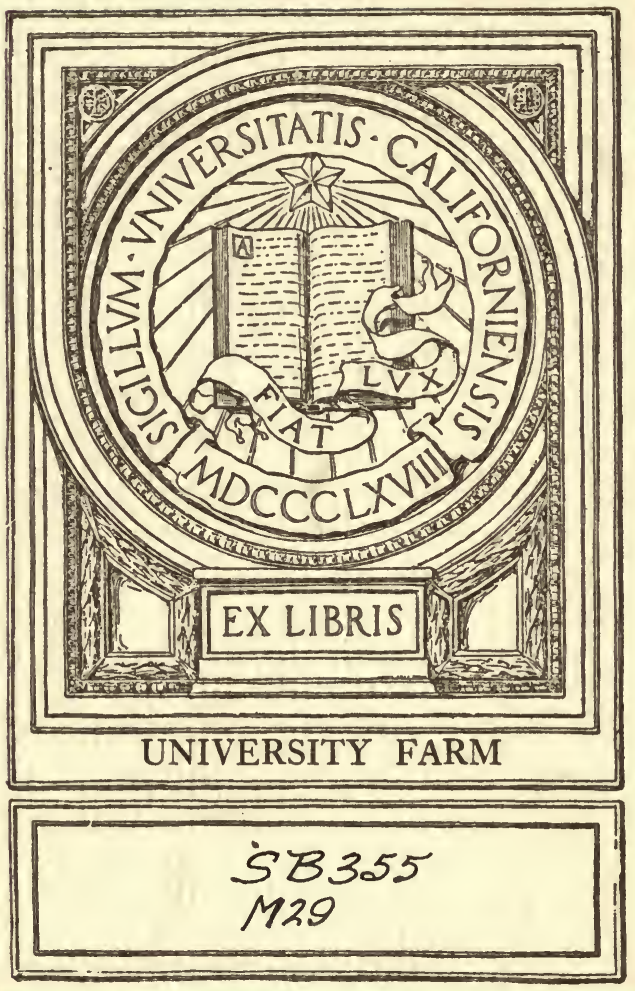


Editns of the Mzaqain

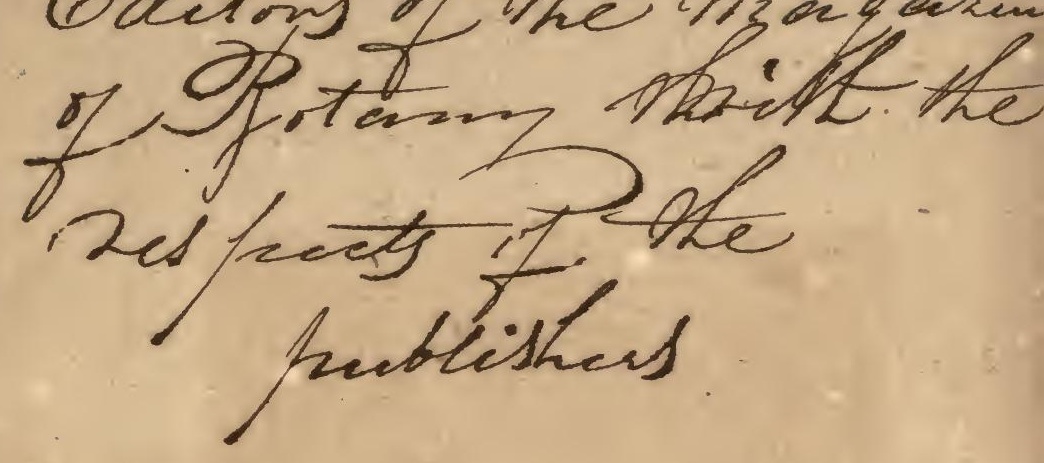





Digitized by the Internet Archive in 2007 with funding from Microsoft Corporation 


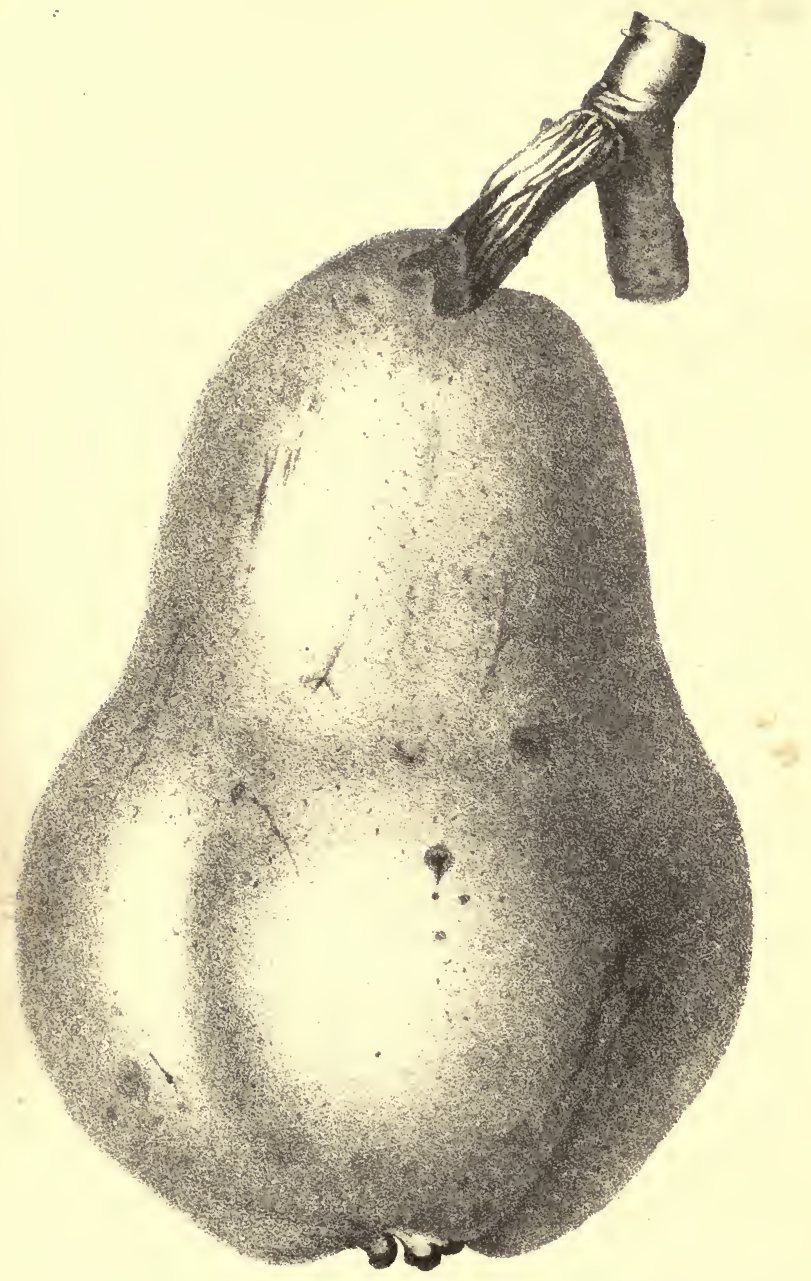

Noores Luth. PHoston.

'Willums' Bon Chretien, or Bartlett Pear. 


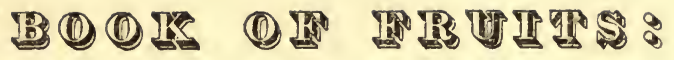 BEING A}

DESCRIPTIVE CATALOGUE

$$
\text { OF THE }
$$

MOST VALUABLE VARIETIES

OF THE

PEAR, APPII, PEACH, PIUM \& CHERRY, FOR

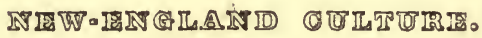

BY ROBERT MANNING.

TO WHICH is $\triangle D D E D$ THE

GOOSEBERRY, CURRANT, RASPBERRY, STRAWBERRY, AND THE GRAPE;

WITH MODES OF CULTURE.

Also,

HARDY ORNAMENTAL TREES AND SHRUBS.

WITI PIATES.

\section{First Series for 1838.}

S A L E M :

PUBLISHED BY IVES \& JEWETT. AND FOR SALE AT THE DIFFERENT BOOK-STORES AND SEXD ESTABTISHMENTS IN NEW-ENGLAND.

1838. 
Entered according to Act of Congress in the year 1838, BY IVES \& JEWETT,

In the Clerk's Office of the District Court of Massachusetts.

SALEA OBSERVER PRESS. 


\section{TABIE OF CONTENTS.}

Page.

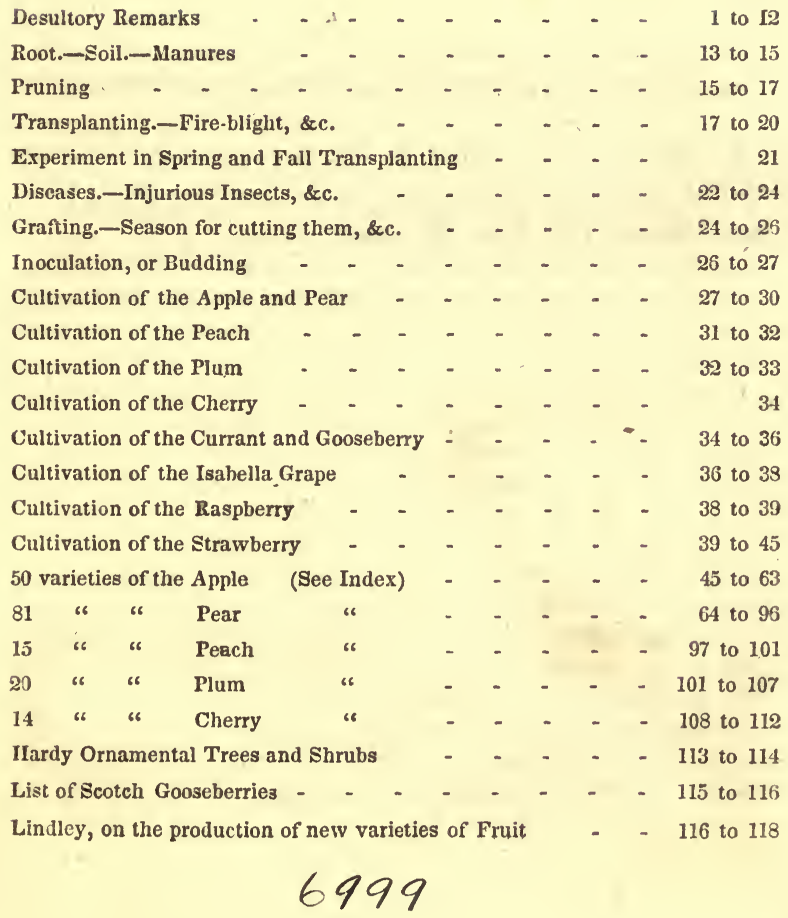


पIF The directions for culsure, \&.e. and the articles on the Strawberry, Currant, Raspberry, Gooseberry and Grape, together with the plates, were furnished hy Mr. John M. Ives. 
DESULTORY REMARKS.

The Ponological Garden was commenced in 1823, with the design of forming a large collection of specimen trees of such varieties of foreign and native fruits, as were hardy enough to endure the inclemency of a northern winter. After a strict examination of the produce of these trees, carefully comparing the wood, the leaf and the fruit, with the figures and descriptions in the most popular works on Pomology, it was intended to select for permanent cultivation, those varieties which were at once fitted to the climate of New England, and of high merit in themselves. In furtherance of this purpose, we have assiduously culled from American catalogues all that we judged worthy of trial, and imported from the first European establishments, the fruits most in repute with the writers of their respective countries. We have never limited ourselves to one specimen, but have in every instance, procured trees of each name from many different sources, in order the more surely to arrive at correct conclusions respecting their identity, as well as to multiply our means of estimating their comparative value.

For donations of scions we are indebted to the liberality of many gentlemen of our own country, who have imported choice fruits from Europe for their own gardens; to the London Horticultural Society, and to the learned Doctor Van Mons, of Brussels, from whom we have received most of those new and admirable Pears which he has, for many years, produced on his own grounds, or obtained from the horticulturists of Belgium and Germany. We have also annually collected scions of all the new fraits of American origin, and propose to continue the collection 
both of these and of trees from the best foreign and native sources. IV shall suhject their produce to the same rigid scrutiny with the contents of the present volume; and shall offer those which prove most valuable and hardy to nursery-men and amateurs, who will thus be enabled to obtain varieties of tried merit, without danger of the necessity of a renewal, at a future period, after waiting many years for the appearance of fruit.

A supplement to this work will be published at the close of every fruit season, describing each desirable kind which has been proved during the season. With the exception of Peaches, we recommend no fruit that will not ripen in any part of New England or New York, and in the southern part of Canada. Our selections have been made from nearly four hundred kinds, which we have raised yearly. Experience has taught us that many fruits, highly extolled by European writers, and doubtless of great excellence in their native soil, either pcrish or degenerąte in our colder regions; and of these and all others which we have found in any respect improper for cultivation, we design hereafter to publish a catalogue.

We do not claim for all the varieties herein enumerated, the distinction of first rate fruits; some are second rate, admitted in considcration of their size, beauty and abundant bearing, though their flavour is not the most delicious. The essential characteristics of a first rate tree are, health, vigor, and fertility; those of a first rate fruit are, magnitude of size, beauty of shape and colour, and richness of flavour. But a small number of fruits, uniting all these qualıties, is known to horticultural science throughout the world. Besides, in regard to the taste of a fruit, the judgment of individuals greatly varies; what one person would pronounce exquisite, might to another seem merely tolerable. In conmenclation, however, of the kinds descrihed in this manual, we confidently declare our conviction, that no possessor of any or all of them would willingly relinquish their culture for the purpose of regrafting his trees with any other varieties.

There is one circumstance to which we venture to call the attention of our readers-that while some recent works on Pomology are compiled from earlier authors, or from information derived at second-hand, the writers themselves seldom having the mcans of observation in their power, we have in these pages described no specimen which we have not actually identified, beyond a reasonable doubt of its genuineness. 
We offer these notices merely as matters of fact, without embellishments. Recording nothing that we have not ourselves witnessed, we have quoted no synonims, and referred to the authority of preceding writers wo farther than to adopt the names by which the fruits are known in the catalogue of the London Horticultural Society, the most complete work on this subject hitherto offered to the public.

The innumerable errors in the names of fruits, and the perplexity and disappointment arising from this cause, are inconceivable to any but a collector. It is very desisable that there should he some acknowledged standard, to whose authority, in doubtful cases of this nature, we might appeal. Nurserymen and cultivators have generally deemed it a point too trifling for consideration. If a fruit was good, the name was supposed to be of no consequence. A better state of things is, however, beginning to prevail, especially in the United States, where a knowledge of the subject is widely diffused, and a laudable solicitude is felt that catalogues should contain no varieties but what are actually cultivated, and ascertained to be identically the kinds which their titles proclaim them to be.

The invoices of trees from France frequently furnish instances of unparallaled ignorance, or even fraud. We have received from what were considered the best establishments, large numbers yearly-on one occasion several hundred-all bearing new and high-sounding names, and the greater part of which were suffered to arrive at maturity; but, with very few exceptions, the fruit was entirely worthless.

There is a peculiar difficulty in making a selection of choice Apples, because, in addition to the very numerous varieties already made known by the different Horticultural societies, and included in the uursery catalogues, we are constantly receiving accessions from cultivators and collectors; and, in travelling through New England, we find in almost evcry town, and, indeed, on most farms, some valuable fruits, of local origin, which have never been introduced to general noticc. Still, we do not despair of success in our endeavors to collect the most desirable kinds, both native and foreign.

A very large number of new pears has been introduced, and was rendered necessary by the degeneracy of most of those fine old varieties, for a long course of years so successtully cultivated in this section of the country. Some of these old kinds still continue to be favorite fruits 
for the dessert, but in general they have become worthless, and are no longer raised on standards, or in the open ground. We are more than compensated for their loss by the new Flemish pears, introduced into the United States by the liberality of the London Horticultural Society, and of Doctor J. B. Van Mons. These new fruits have in most instances fulfilled our highest expectations.

There has also been a large accession to the number of fine Plums cultivated in New England, both by introductions from Europe, and by new varieties of local origin.

From our collection of Plums, not yet proved, we have much to anticipate; we earnestly hope to find among them fruits not only of great beauty and delicious flavour, but free from those fatal diseases which now disfigure and destroy the finest trees of this speeies.

We have obtained fewer additions to the catalogue of Cherries than to that of any other fruit; partly bécause the season for them is so short, that a few varieties suffice for the interval from the first to the latest ripening; and because we already possessed a few fine sorts, which neither in their growth nor fruit partook in the smallest degree of the degeneracy of the old pears, and some other species; but principally, at least this was our own case, from the difficulty of protecting them from the birds. The last season we had but few perfect specimens, except the Bigarseau. We expected to prove and bring into notice many new and valuable sorts, and our disappointment may be imagined at finding ourselves in every instance anticipated by these innocent depredators. Such has been the security they have felt in our grounds, and so great their increase, that not only Cherries, Gooseberries and Currants, but Apples, Pears and Plums have shared in their ravages, and given proof of their good taste, which invariably leads them to the finest fruit; and it may hecome a matter for serious consideration, whether in continuing our protection to them, we do not risk the total loss of some of the most desirable appendages to the dessert.

It will be observed, that but few Peaches are included among our descriptions. We had collected from Europe many fine varieties, and from New York, New Jersey and Pennsylvania, a very large number of the most celebrated in those States, where the climate is so favourable to their cultivation; these trees were planted out as specimens, and for many years produced an abundar.ce of delicious fruit; but they have 
all, even the young trees from which we had hoped a future supply, fallen victims to the severity of our winters, and the recent short and unpropitious summers; and we believe the destruction has extended over the whole of New England. IVe still trust, however, upon hardy stocks, and with the influence of more genial suns, to be able at some future time to exhibit a larger number of specimens than we have ever yet done, of this fruit, the most exquisite produet of the temperate regions.

As a source of income, it is believed that no pursuit could more safely be relied upon than the cultivation of fruit for the markets of the principal cities of the United States. Many fearful predictions have been utlered by those over prudent people who foresee loss and disappointment in every undertaking; but still we find the demand for this luxury increasing, while the prices obtained for the finest sorts have not ciiminished, but rather advanced. It is true that the taste of the public has grown fastidious, but to provide "for this the grower has only to become more scrupulously nice in his choice of varieties, of which the different Horticultural societies have made known a multitude sufficiently excellent to gratify the most refined palate.

Owners of land would find it for their interest to raise, in orchards, on an extended scale, the finest large winter baking pears, either for the supply of our own markets, or for exportation to the South, where they meet a ready sale at a price which will amply repay the cost and trouble of cultivation.

We well remember the discouraging advice that we frequently received at the beginning of our course as a cultivator. We were too old, it was said, to expect to reap, in our own persun, the fruits of our labours; yet in spite of these and many other prophecies of the same nature, we persevered, and have not only had the satisfaction of raising a great variety and abundance of fine fruit, but of producing, from the seed, the Apple, Pear, Peach, Plum, Cherry, Nectarine and Currant. At one time we planted a peck of the Siberian Crab Apple, and part of the plants remg suffered to bear, the countless varieties in the size, shape, and colour of the fruit were well worthy the attention of the curious; we believe not one specimen of all that we noticed precisely resembled that from which it originated. At another time we collected in the market at Boston, a large quantity of peach-stones; these were planted in close rows in poor land, which caused many of them to hear the fourth year. We tasted of the fruit from more than six hundred trees; they were of every 
degree of merit; some of high excellence, so valuable that we regretted they should share the fate of our whole collection of peaches, which, as we before observed, were destroyed by the late unfavorable seasons.

We mention these seminal productions only to show that our labours meet a speedy reward, and that a person is seldom so advanced in life that he may not reasonably look for both requital and gratification in so laudable a pursuit. But to a young man with the advantages of fortune and a familiarity with the modern languages, researches of this nature would open an inexhaustible source of enjoyment. He could scarcely be more honorably and usefully occupied than in collecting and identifying fruits, and introducing them to the notice of his countrymen; nor better rewarded than in witnessing his anticipations, from year to year, continually realized and continually renewed. The same ardour which characterises the collectors of shells, birds and insects, would produce, in Horticulture, far more delightful and more noble results.

A division of the pursuit, so that the attention of one person could be exclusively direcled to one species of fruit, would probably greatly facilitate the progress of investigation, and lead to many satisfactory conclusions respecting the varieties most worthy of cultivation. If France has produced her Duhamel, Belgium her Van Mons, and England her Thompson, is it unreasonable to seek among geutlemen of leisure and education in the United States, for one, who following in the footsteps of these illustrious men, with the advantage of the light derived from their rescarches, shall compensate for the long delay of the experimental garden, promised by our own Horticultural Society.

In speaking as we have, of the annoyances sustained from birds, we are still fully persuaded that these plunderers, as they are sometimes called, more than compensatc for their occasional inroads upon our orchards by their services in the spring, and also during their incubation, in destroying insects. We too often, perhaps, notice the former, while the latter are remote, or not obtrusive.

In early spring and during the breeding season, we see them every minute of the day in continual progress, flying from the nest for a supply, and returning on rapid wing witl a grub, a catterpillar, or a small reptilc. The nnmbers captured by them in the course of these travels are incredibly numerous, keeping under the increase of these races. ITe have seen the Ampelis, or Cherry Bird, that remarkably silent and dovc- 
like species, in great numbers early in the spring, and also during the tıme of nidification upon our apple trees, when the canker worm was about half grown, destroying them in great numbers. It is also known to every observer of nature how extremely fond our common and familiar robin is of grubs, those insidious enemies to our garden crops, as well as the slimy slug which often infest our young pear trees; and any individual who may have had the robin as a cage bird, is aware of the quantities of insects, or worms, he will devour in a day; and when we take into view the circumstance of these birds having usually two broods in a season of four each, it will give us at least some idea of the quantity of this peculiar food required for at least four months in each year. And although called plunderers, they are in fact benefactors likewise, seeming to be appointed by nature as agents for keeping under the increase of these races, $\mathrm{N}$ early all our hard-billed or granivorous birds, are in spring and the early part of our summer decidedly insectivorous. "Public economy and utility," says one, "no less than humanity, plead for the protection of the feathered race; and the wanton destruction of birds, so useful, beautiful, and amusing, if not treated as such by law, ought to be considered as a crime by every moral, feeling, and reflecting mind." 



\section{BOOK OF FIRUTS.}

\section{ROOT.-MANURES.}

The root being the commencement and foundation of Trees, its office is to collect and apply the food which forms and determines its growth; hence if the roots grow luxuriantly, the branches will also, - and the reverse. "It often happens," says Miller, "that the roots of trees are buried too deep in the ground, which in a cold or moist soil is one of the greatest disadvantages that can attend Fruits;-for the sap in the branches being by the warmth of the air put strongly into motion early in the spring, is exhausted in nourishing the blossoms, and a part of it is perspired through the wood branches, so that its strength is lost before the warmth can reach the shoots to put them into an equal motion in search of fresh nourishment, to supply the expenses of the branches, for want of which the blossoms fall 
off and decay." Most trees will thrive if they have two feet in depth of good earth, especially when their roots spread near the surface ; for whether that which supplies food for the Tree be a black, yellow or brown loam, it can only be furnished within a certain depth from the surfacè, or within the influence of the sun and air. Large roots, running deep and spreading wide, may be necessary to produce large Timber Trees, but not Fruit Trees, for these are more prolific when their roots are much divided or fibrous, and kept near the surface of the soil. With regard to the manure for Fruit Trees, Bradley, Hitt and Miller, "consider the food of plants to be salts, which every species of earth contains within itself, and that according to the proportion of salts contained in each kind of soil or manure, will its prolificacy be." We are of opinion from the use which we have made of the sea marl or muscle bed, that it is on the whole the best manure, either for top dressing or shallow ploughing, of any substance in use among us, particularly when applied to light soils. It is said by some, that salt is valuable only as a chemical agent, by destroying and hastening 
the decomposition of animal and vegetable substances, and by its deliquescence in many instances increasing the fertility of soils. It is undoubtedly true, as said by Sir Humphrey Daviy, that the great object in the application of manures should be, "to make it afford as much soluble matter as possible to the roots of the plant, and that in a slow and gradual manner, so that it may be entirely consumed in forming its sap and organized parts." Vegetable manures in general contain fibrous and insoluble matter, which must, says the same writer, "undergo chemical changes before they become the food of plants."

If the situation or soil in which Fruit Trees are placed, retains stagnant water, destructive to their healthy growth, drains must be made to carry it off, or means taken to prevent the roots from running into it.

\section{PRUNING.}

It is rather difficult to give upon paper very explicit directions in this department of culture, as many varieties of Fruit Trees require different management: Peaches, cherries, and plums are always in the greatest vigor when 
they are the least maimed by the knife, for when these trees have large amputations, they are very subject to gum, and decay; so that it is certainly the most prudent method carefully to rub off all useless buds, when they are first produced, and pinch others where new shoots are wanted to supply vacancies. Fruit Trees in this latitude should not be pruned in the Fall or Winter, or before the sap is in motion, as they are at those times exceedingly apt to crack or canker. The proper season for pruning we consider, is immediately upon the swelling of the buds, or expanding of the leaves, as at this time the sap being in vigorous motion, the wounds soon heal over. Every limb should be cut close to the main stem, and if sawed off, should be then finished smoothly with a sharp knife. If the limb is large, a composition of red ochre and tar should be spread upon the end to keep out moisture, \&c., or the composition hereafter named. From the strong and vigorous growth of Fruit Trees in our country, close pruning is less necessary here than in England, from whence we have derived most of our instructions; excessive pruning with us is apt 
to generate suckers from the limbs. Judicious pruning, however, will promote health and early fruitfulness. Trees differing, as they do in form, require very different treatment in pruning. Coxe, of New Jersey, says, " those who can conveniently do it will find a benefit from forming the heads of their trees in the Nursery, the year before they remove them-when transplanted, they will thrive more rapidly from not having been pruned at the time of removal."

Every limb which crosses another should be taken off. In pruning apple and pear trees, the external branches should be every where rendered thin and pervious to the sun.

\section{TRANSPLANTING.}

In the removal of trees, care is necessary to. obtain as much of the roots as possible, and in re-setting, that none are doubled back and distorted. Cutting off smoothly the end of each root that may be broken or cut by the spade, is indispensable, and all fibrous roots that are injured should also be cut close to the root upon which they are attached; the root or stem should be pressed close down on the B* 
soil, so as to place the roots in a horizontal direction, and all of them drawn out straight like a fan, or rays verging from a centre to a semicircle, and the soil thrown evenly over; the tree should not be shaken after the earth is placed upon the roots, as is too generally practised; for when a tree is thus raised up, the small roots or fibres will be drawn out of their places, and when the stem is thrust down again, the roots being too weak to force their way back into the soil, will be doubled up, which often causes knobs, and throws out suckers; neither will the earth require to be trodden down hard, but gently; or if it be a dry or loose loamy soil, setting in puddle, which is to water as you set it;-this last method is undoubtedly the best, when an individual has time to attend to it,-it is a slower process. Copious watering after $a$ tree is set, is often very prejudicial, by washing the soil from the roots.

Fruit Trees should rarely be placed deeper in the ground than they originally stood in the Nursery. Pear trees bear their fruit on short buds, or spurs of one, two, three or more years growth, from the strongest branches; and the 
same spurs will continue to produce fruit for a great length of time; but they do not often produce fruit until they have a surface of branches very large in proportion to the sap supplied by the roots. Thus we find that when pear trees are planted in a deep, rich soil, they grow rapidly, and therefore require a number of years to bring them to a bearing state; on the contrary, when growing in a light or dry shallow soil, they collect but a small quantity of sap, and require but a confined surface which is produced in a short time, and they are consequently brought to a bearing state in a few years. Wherever canker or gum appears, the decayed or infected part must be cut entirely out, and some soot moistened and rubbed over the wound, or the composition hereafter named. This will generally prevent its spreading further, and save the branch.

With regard to what is called Fire-blight, which occasionally effects the pear tree, during the months of June and July, causing the branch to turn black and its leaves to wither, and which may sometimes be caused by forcing or high manuring, or to the duration of the vari- 
ety (as natural trees are seldom if ever attacked by it) we know of no better course than that which we should pursue in the case of the black warts, or excresences upon the plum, which is, to cut off at once the limb just below the affected part.

If trees are found to grow too luxuriantly, and to form only wood for years, even afte they are of sufficient size and age for the production of fruit, the earth should be removed, just before the frost sets in, and a proportion of the deepest growing roots cut off, thus checking its luxuriousness, and rendering it more fruitful. This question is often asked, which is the best season for removing trees, Spring or Fall? Horticulturalists are about equally divided, scme preferring one and some the other. We think in ordinary seasons, provided it can be done early, that Spring is preferable, particularly for stone fruit and pears upon quinces. Lindly, a popular English writer, says that "Trees cannot be removed from the Nursery too soon after the wood has become ripe, and the leaves fallen off; for between this time and the Winter many of them will make fresh roots, and be prepared to push forth their young shoots with much more vig- 
or in the Spring." This will not apply to New England; cold weather sets in too early after the fall of the leaf for this ever to take place, and we think it extremely doubtful that this can ever occur in the climate of England. The impression that fibres will form in the Autumn from newly set trees is common, but we have never witnessed it. The following experiments in Spring and Fall planting have been made at our Nurseries, viz: We received from Albany in November, 1836, two hundred pear trees, grafted on free stocks, whicis were immediately set out; and on the following night the ground was completely frozen. They all, with the exception of ten, leaved out the following Summer.

In March of the next year, 1837, we received from France the same number of pears grafted upon quinces. When they arrived at Boston, the frost prevented our setting them, and they were immediately taken to Newton, and placed in Mr Kenrick's Moss House. In the course of three or four weeks they were received at our grounds in North Salem, and set out. We lost but eight of these trees; six of them bore fruit the same season. 
DISEASES-INJURIOUS INSECTS, SC.

The injuries and diseases to which fruit trees are subject, are often difficult to be accounted for, and the various methods devised for their correction so abundant, that the space allotted in this small treatise will allow us to select but a few of those which we think on the whole best.

The following remedy is found to be the most effective in preventing further decay, and restoring a bealthy regetation, answering a double purpose, being also an excellent grafting composition. It is given thus :-

Take one pound of pitch, one pound of rosin, half pound beeswax, quarter pound lard, quarter pound turpentine, melted and mixed ; spread evenly and thin, with a brush upon soft kentish cap paper or strips of cotton cloth. This compound will resist the force of washing rains, frost, drying winds, and the influence of a changeable atmosphere.

Now prepare the tree properly for its application, by cutting away all the dead, decayed, and injured parts, till you come to sound wood, leaving the surface very smooth, and 
rounding off the edges of the bark with a sharp drawing knife; then lay the plaster over the part cut away. In hollows of trees, you must scoop out all the rotten, loose, and dead parts, till you come to the sound wood, and then apply the composition as above. With regard to the destruction of blighting insects, the practice of burning weeds, wet straw, hay, \&c. to the windward of trees, particularly when sulphur is added, is probably as good a method as can be adopted. Wood ashes sprinkled upon the leaves of pear trees, infested by the slimy slug, particularly if it is done during wet and drizzly weather, we have found very effective in destroying them. The canker which destroys many of our fruit trees, is said by Scotch gardeners, to be owing to a stintiness that takes place in the trees from a bad sub-soil. With regard to the insects that infest trees, we consider the borer the most destructive. The Philadelphia Horticultural Society awarded to a Mr Snyder, the premium for the best assortment of fruits exhibited at their show. This man had been in the habit of placing ashes of anthracite coal about the roots of his fruit trees, and to this circum- 
stance he attributed their preservation from the attacks of insects. We know not, however, a more effectual way of destroying this insidious insect, than by cutting them out.

\section{GRAFTING.}

Grafting is the taking of a shoot from one tree and inserting it into another, in such a manner, that both may unite closely and become one tree. These shoots are called scions or grafts, and in the choice of them we observe the following directions. 1st. That they are shoots of the former year. 2d. Always cut them from healthy, fruitful trees. 3d. Those are preferable which are taken from the lateral or horizontal, rather than from the strong perpendicular shoots.

Grafts may be cut from the trees before the buds begin to swell, in February or March, or late in the Fall. They should be buried halt their length in the ground, or in a cool and dry cellar. The season for grafting must be regulated by the weather, which is so uncertain in our climate, that we think it better to defer the operation till the circulation of the sap is brisk, and the buds of the stocks are 
putting forth their leaves. In a long continuance of dry weather, grafts frequently fail of taking. This operation is generally more successful, if performed in a moist or cloudy day.

Among the various methods of engrafting, the following we consider as successful as any described, viz: cleft or slit-grafting. It is performed on stocks from one to two inches in diameter. The head of the stock being carefully cut off in a sloping direction, a perpendicular cleft or slit is to be made, about two inches deep towards the back of the slope, into which a wedge is to be driven, in order to keep it open for the admission of the scion; the latter must now be cut in a perpendicular direction, and in the form of a wedge, so as to fit the incision in the stock, in such a manner that the inner bark of both the stock and scion may meet exactly. It is then covered over with grafting clay, composed of half cow-dung, free from litter, and fresh loam well incorporated, or the following composition, which is made of equal parts of rosin, beeswax and tallow, or lard, melted and spread upon strips of brown paper or cloth. We have practised grafting under the bark in Spring, in the manner of budding with good 
success, applying in every case the composition in preference to the clay.

\section{BUDDING, \&c.}

Inoculation or budding, is commonly practisèd upon stone fruits, such as peaches, cherries, plums, \&c., and we think it preferable to grafting for nearly all kinds of fruit.

The object in budding is the same as in grafting, and depends on the same principle; all the difference between a bud and a scion being, that a bud is a shoot or scion in embryo. When grafting has been omitted, or has failed in Spring, budding comes in as an auxiliary in Summer. The season for budding is from the beginning of July to the middle of $\mathrm{Au}$ gust, the criterion being the formation of buds in the axillæ of the leaf of the present year. The best buds are those on the middle of $a$ young shoot, not those at the lower end; stocks for budding may in general be much smaller than for grafting, as the operation may be performed on the same year's shoot. The French enumerate twenty-three varieties of budding; but the variety in general use with us is the following, called shield or $\mathrm{T}$ budding. It is thus performed: Select a smooth part of the stock, rather from, than towards, the sun; 
then with the budding-knife make a horizontal cut across the bark, quite through to the firm wood; from the middle of this transverse cut, make a slit downward, an inch or more long, going also quite through to the wood. This done, proceed to cut out from the scion the bud, cutting nearly half way into the wood, then with the thumb nail or point of the knife take out the wood, observing that the eye or germ of the bud remains perfect; if not, and a little hole appears in that part, it is imperfect, or as gardeners express it, the bud has lost its root and another must be prepared. Many gardeners do not take out the wood, considering it unnecessary, but insert the bud with the wood attached. With regard to the future treatment, see the article on the cultivation of the Pear.

\section{APPLES.}

With regard to the transplanting, pruning, \&c. of Apple Trees, the directions hereafter given in the article "Cultivation of the Pear," will generally-apply to this fruit.

CUltivation OF THE PEAR.

Pears are propagated by grafting in the Spring, or budding late in Summer, either 
upon the common pear stock, or upon the quince. The pear-stock is undoubtedly the best for those intended for open standards or orchard planting, but the quince stocks (which have for a long time been used by the French for dwarfs or half-standards) occupy but little space in a garden, are productive, and the fruit they produce is frequently of a larger size than the same grown on pear stocks. Dubreiul recommends the quince stock for clayey and light soils, and the free stock pear, for chalky and silecious soils. Grafting or budding pears upon the white thorn is sometimes practised with success. The quince stock should be budded at or below the surface of the ground, when the bark will separate entirely from the wood, which in this latitude takes place about the last of July or early in August.

The following Spring, when the bud commences pushing, cut the stock off to within three inclies of the bud, and in the next season finish or cut off the snag smoothly to the bud or shoot. In the third season, when the trees are removed to the situation in which they are to remain for fruiting, be careful to 
re-set them at least one inch below the insertion of the bud, as shown in the following cut of a trained tree.

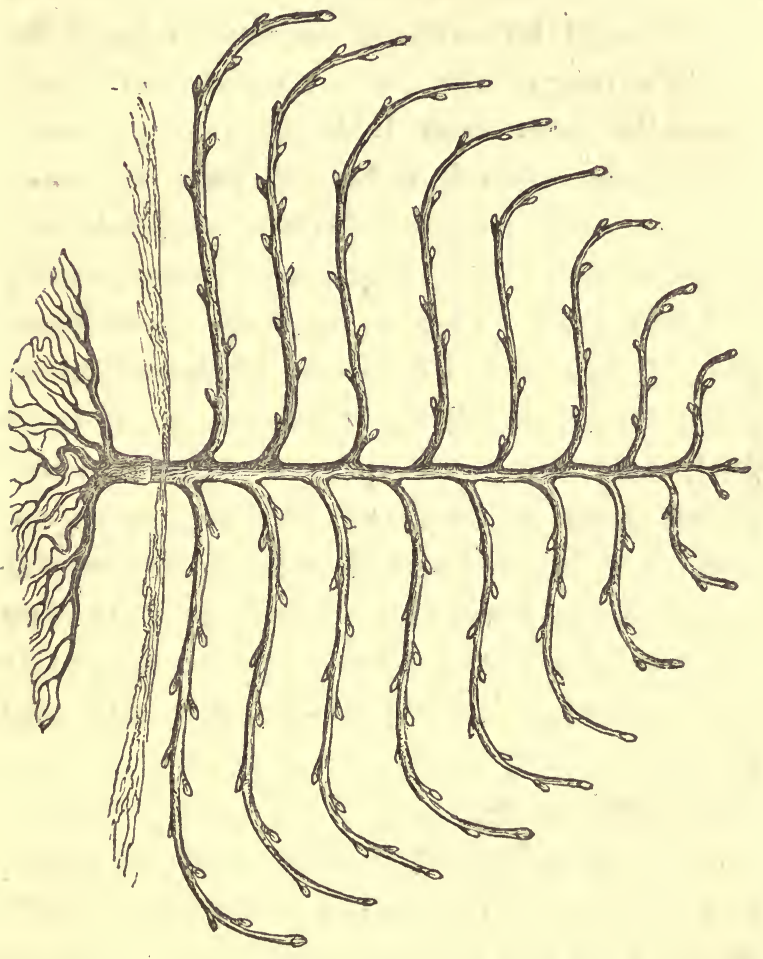

This cut of a dwarf tree is placed to show the position of the quince stock, when grafted or budded with the pear one inch below the surface of the soil.

$$
C^{*}
$$


Setting the stock one inch below the bud or scion, will preserve it from the cold in Winter and the insidious borer in Spring. In order to produce fruit early, the side shoots or spurs should be suffered to remain upon the whole extent of the tree, as they will then generally form fruit buds upon each spur. These trees are admirably adapted for small gardens, occupying but little space, less exposed to high winds, affording greater security to heavy fruit. One of our best new European Pears, the "Duchess of Angouleme," when grown as a dwarf produces a fine large fruit, but small and greatly inferior when grown upon a standard. "When pears are grafted or budded on the wild species, apples upon crabs, and peaches upon peaches, the scion is,in regard to fertility, exactly in the same state as if it had not been grafted at all; while on the other hand, a great increase of fertility is the result of grafting pears upon quinces, peaches upon plums, apples upon the thorn, and the like. In these cases the food absorbed from the earth by the root of the stock is communicated slowly to the scion." No other influence have we ever noticed exercised by the scion upon the stock. 


\section{PEACHES.}

All the varieties of peaches are generally continued by budding, and new ones obtained by planting the stones, which should be done as, soon after they are separated from the pulp as possible. The plum is a good stock to engraft this fruit upon, particularly if wanted for dwarfs or trained to espaliers. Among the casualties to which these trees are subject, the worm, or grub, as we call it, is the most destructive. Its attacks ordinarily begin in the stem, near the surface of the earth; and if not arrested, will soon reach the root, causing gum to exude from the wound. The following are some of the remedies resorted to for their destruction. 1st. The application of boiling water to the roots : 2d. A similar application of unslacked lime, about one quart to a tree of ordinary size. 3d. Removing the surface of the soil and substituting tanner's bark. Removing the earth in the month of November and exposing the roots to the action of frost during the Winter, as has been sometimes done, we should not recommend, as it would often prove fatal to 
the tree. In the state of New Jersey, where this fruit is raised in great quantities, they adopt the following practice to destroy this insect. In the Spring, when the blossoms are out, they clear away the soil, so as to expose the root of the tree, to the depth of three inches; then surround it with straw about three feet long, applied lengthwise, so that it may have a covering one inch thick, which extends to the bottom of the hole, the buttends of the straw resting on the ground at the bottom; binding this round the tree with three bands, one near the top, one at the middle, and the third at the surface of the earth; they then fill up the hole at the root with earth, and press it closely round the straw. By this process it is said that the fly is prevented from depositing its egg within three feet of the root; and although it may place the egg above that distance, the worm travels so slow that it cannot reach the ground before frost, and therefore is killed before it is able to injure the tree. For Budding, \&c. see the article under that head.

\section{PLUMS.}

The plum tree flourishes best in a rich, sandy loam, neither too dry nor too moist. 
A cold, wet, clayey soil, or a dry sandy situation is not considered so favorable. They thrive best in our neighborhood near the borders of the sea, which we think is owing to their being in such situations not so subject to the insect called Curculio, which perforates and destroys the fruit; these insects are not so abundant here as in the vicinity of Boston; they are said to avoid the salt air.

Salem, which may almost be called a peninsula, being nearly surrounded by the sea, has been for many years known to produce annually more fruit of this kind than any other city or town in the State. Plum trees are also liable to be attacked by an insect which causes large black bunches or warts to be formed on the limbs, but as there are several varieties which are said to be exempted from this disease, we hope to find among upwards of one hundred kinds we have received from different sources, a desirable variety which may be always free from this destructive insect, and which we may describe hereafter. 


\section{CHERRIES.}

Cherries, like stone fruit in general, are usually produced by budding, seldom by grafting ; if by the latter process, we think it should be done early in the Spring, particularly if by split grafting. Grafting under the bark can be done later and with more certainty of taking. Budding in July or August, we should decidedly prefer. With regard to this fruit, as is the case with strawberries, various opinions exist as to the most desirable sorts for culture. The black Tartarian and the Gridley Bigarreau or apple cherry, are highly prized as Black Hearts. The white Bigarreau and the Napoleon as white hearts, are probably as productive, and desirable, as any we have as yet seen.

\section{CURRANT AND GOOSEBERRY.}

These are easily raised from cuttings, provided you have moist soil, by putting them into the ground immediately upon the falling of the leaf, when the shoots of the Summer are well ripened, or very early in the follow- 
ing Spring; the part inserted into the ground should be cut across a bud, and then set from three to five inches deep, according to the nature of the soil and situation, being careful to .rub off all the buds below the surface; they should not be suffered to push near the ground, but as buds appear they must also be taken off, training them as dwarfs or half standards. Both currants and gooseberries bear their fruit on the last year's shoots, and on short natural studs or spurs. The gooseberry will continue to bear on the same buds or spurs for many years, particularly if the branches are kept open and free for the admission of the sun and air. To have large and fine fruit from the currant and gooseberry, they should be trained to resemble a well formed tree in miniature; the ground near the bushes should be well manured, particularly the last named fruit. The gooseberry requires a rich loan, free from weeds. Early in the Spring, spade carefully around the roots, turning the soil well over; prune them by cutting out every worn out, decayed or irregular branch; let none be permitted to grow across each other; cut out all the superabundant, lateral shoots 
of the last summer, on the old wood near the ground, only retaining here and there one in vacant parts, to form successional bearers, and to supply the places of unfruitful branches. Gosseberries are liable to mildew, if placed in a confined situation; they want a free, open exposure.

The varieties of this fruit are very extensive, and of various colors, white, green, yellow, red, and dark purple. They differ much in quality; some of the largest fruited kinds having a thick skin, are fit only for cooking, while others are fine for the table. In selecting from the catalogues, we should send for those, without regard to names, which have been tested by the nursery-man, and proved to be the best flavored.

GR APE.

The ripening of foreign grapes in the open air, in the climate of New England, is very uncertain; and the necessity of covering them in Winter will undoubtedly prevent their gencral culture. The editor of the Magazine of Horticulture, Mr. Hovey, justly says, "that the cultivation of foreign grapes in the open 
air, must, we think, except in cities, be generally given up. For three or four years past scarcely a crop has ripened." Among the varieties of native grapes, we should not recommend the Catawba, although considered by Mr. Adlum, "to be worth all others as a wine grape ;" still its lateness is a great objection, it never having ripened with us. We should decidedly prefer the Isabella. This fine native grape was introduced into New York about sixteen years since, by Mrs. Isabella Gibbs, from South Carolina, and was named Isabella by William Prince, Esq., of Flushing, L. I. The vine is extraordinary for the vigor of its growth and great productiveness. A single vine, in 1820, produced eight bushels. It is a late fruit, and in a shady situation or upon an open trellis rarely if ever ripens its berries. It should be trained to a wall, fence, or out-building, where it can receive the sun's rays nearly the whole day, at least from its rising till three in the afternoon. This vine wants no protection in Winter, and the best season for pruning, we consider early in April. They may be increased by layers or cuttings. 
Although grape vines are generally pruned in the Fall, which may be the best season for the foreign grape, we still, from our own experience with the Isabella, decidedly prefer the Spring for this variety. Pruning vines in the Spring is often objected to from fear of their bleeding. This, however, rarely takes place,provided it is performed early in April,and the section which is laid bare be presented to the sun's rays, which will almost invariably close up the sap vessels; they should, therefore, be cut from the outside, inward, in an oblique direction.

\section{RASPBERRIES.}

The white and red Antwerp are the two most desirable sorts for cultivation; they should never be grown together in masses; as the red, being more inclined to wood, will eventually choke or injure the growth of the white. The time to plant young sucker shoots, of last summer, is early in Spring; choose them strong, about three or four feet growth, detached with good roots, and prune the weak top part; plant them in rows four feet and a half or five feet asunder by three feet, in the rows; prune old plantations, cutting out the 
dead stems, or the last Summer's bearers, for the same shoots or stems never bear but once, being succeeded by young ones produced from the root every summer, which become barren next year, and perish the following Winter, and should now be cut out as above, close to the ground; and then thin the young shoots to three, four, or five of the strongest on each stock, and prune them at the top. A cultivator near Boston says-"The Raspberry should always be cut about five feet high ; it increases the quantity and size of the fruit, as well as encourages the growth of the suckers, for the following year. It should, however, not be done until all chance of severe frost is over; yet before the buds shoot, the stems ought afterwards to be lightly tied together at the top, or to stakes placed in the ground."

\section{STRAWBERRY.}

There are several varieties of this most delicious fruit, and many opinions relative to the best flavored and most prolific sort. At Albany they commend the Methren Castle as the most profitable and productive; at Roxbury the royal scarlet and pine apple. A cul- 
tivator at Dorchester highly approves of the early Virginia scarlet, which last is probably as productive as any for general culture. The Downton Red Alpine, (without runners,) and Keen's Seedling, are also desirable varieties.

Propagation.-With the exception of the bush Alpine, which is only increased by divisions of the root, all the varieties multiply spontaneously every season, by numerous runners from the parent plant, which, rooting and forming a plant at every joint, only require, for the production of fruit in abundance, removal to a bed where they may have room to flourish. Such plants will bear the Summer succeeding the planting, and in the second year will be in full perfection. The best way is to supply a new plantation, with plants which have been taken from runners and set out in nursery beds the previous season. But where such cannot be had, those of the present season will answer.

Soil and situation.-Strawberries will grow and produce fruit on almost any soil of moderate fertility; but they are most productive on a deep rich loam. They should be in an open. situation, exposed to the sun and air, and not 
under trees. The Alpine strawberries, however, admit of being placed in a more shady situation, as it is during the hot and dry season of the year that they are intended for bearing; which they will not do if allowed to suffer from drought; few are willing to take the pains to-water them as much as they would require.

Transplanting.-The best time for doing this is in the Spring; but if performed with proper care, they succeed nearly or quite as well when transplanted early in Autumn, say in the early part of September. The ground should be well manured and dug, a month before transplanting. The chief care required when the work is done in Autumn, is to guard against the plants being thrown out by frost, which is best effected by treading the soil closely about the roots.

Culture.-The distance of the plants asunder, where the soil is rendered sufficiently fertile, should be, for the larger varieties (such as Methven and Keen's seedling,) twenty inches from row to row and fifteen inches in the row ; the smaller varieties may be a little nearer together. This distance may seem too great, $\mathrm{D}^{*}$ 
but it is much better than crowding the plants too closely, which is the more common error. It is only by affording sufficient room for the plants to receive the benefit of sun, air, and of culture, that the fruit will ripen early, and acquire a good size and agreeable flavor. Keen, of Isleworth in England, a most successful cultivator of this fruit and who raised the celebrated Keen's seedling, says, in speaking of the large distances he adopted in planting,"these distances I find necessary, for the trusses of fruit in my garden ground are frequently a foot lung." "The following is his method of culture, in his own words: "After the beds are planted, I always keep them as clear of weeds as possible, and on no account allow any crop to be planted between the rows. Upon the growing of the runners, I have them cut when necessary; this is usually three times in each season. In Autumn I always have the rows dug between; for I find it refreshes the plants materially; and I recommend to those persons to whom it may be convenient, to scatter in the Spring, very lightly, some loose straw or long dung between the rows. It serves to keep the ground moist, 
enriches the strawberry, and forms a clean bed for the trusses of fruit to lie on ; and thus by a little extra trouble and cost, a more abundant crop may be obtained. A short time before the fruit ripens, I always cut off the runners, to strengthen the root; and after the fruit is gathered, I have what fresh runners have been made,taken off with a reaping-hook, together with the outside leaves around the main plant, after which I rake the beds, then hoe them, and rake them again. In the $\mathrm{Au}$ tumn, unless the plants appear very strong, I have some dung dug in, between the rows, but if they are very luxuriant the dung is not required; for in some rich soils it would cause the plants to turn nearly all to leaf. I also have to remark, that the dung used for manure should not be too far spent; fresh dung from the stable door, is prefererable to spit-dung, which many persons are so fond of."

In thus recommending a thorough method of culture, we would by no means wish to discourage those who have not yet attempted raising this excellent fruit, and who think they cannot afford to adopt such culture, from attempting it altogether; indeed if proper va- 
rieties are obtained, good crops may be had with little or no care after transplanting; we have known beds almost untouched for years to yield plentifully. Nevertheless, we consider the cheapest method, ultimately, of raising this fruit, is by thorough culture; that the greatest amount of fruit is obtained in this' way for the care and labor expended, and that the quality is so much superior to that obtained from slight culture, as to give the former practice very decided advantages. When the beds have much diminished in their product, new plantations must be made to supply their place. This generally takes place in four or five years.

A grower of this fruit in New York subjoins his method of cultivating, thus-"In the Fall, cover the beds slightly with straw, and burn all down; then dig in between the hills with a trowcl or deep hoe, rake smooth, and replace with a fresh dressing two inches thick, for winter protection, \&c. The hills ought to be no more than twelve inches apart, and two or three stems in a hill. While the fruit is setting, water morning and evening, with a table spoonful of salt to each pail of rain or 
river water; if well water, it should be exposed to the sun some time. A bed planted from any good variety in full bearing, will, thus treated, always insure a good crop. Early in September is the best time to plant, choosing the first made runner plants, or some offsets for immediate bearing. The runners will come in, the second and third season."

\section{A P P IES.}

\section{No. 1. Early Harvest.}

This is the earliest apple worthy of cultivation: the form is flat, of medium size; the skin when perfectly ripe, is of a beautifully bright straw color; the flesh tender and sprightly; if gathered before they are fully ripe, it has too much acidity. The finest fruits are those which drop ripe from the tree; the branches make very acute angles, by which it is readily distinguished from most other trees in the orchard; it bears young-ripe in July and August. 


\section{No. 2. Early Bough́.}

This is a large handsome apple, the form sometimes oblong, the skin a pale yellow, often with a bright red tinge, the flesh sweet and tender; it is a good bearer, and deserves extensive cultivation. Ripe in August.

No. 3. American Red Juneating.

This apple is of medium size, oblong; the skin is a beautiful red, slightly streaked and mixed with yellow; the flesh is rich, sprightly and good; the tree is of upright growth; it bears well and ripens in August. Although it bears the name of American Red Juneating, we have strong doubts of its having originated in this country; we think it may be the striped Juneating of Ronald.

No. 4. Summer Queen.

A large oblong apple, striped with red on a yellow ground; the flesh is yellow, very high flavored, and excellent. The tree is of vigorous growth, a great bearer. Ripe in August.

No. 5. Early Red Margaret.

A middle sized apple; the shape round, somewhat flat; the skin a greenish yellow, 
striped with dark red; the flesh white, juicy, and agreeable ; it bears early and abundantly. Ripe the middle of August.

\section{No. 6. Summer Rose.}

A very beautiful and excellent fruit; the size is moderate; the form round; the skin yellow, striped, and mottled with red; the flesh is sweet, juicy, and fine. Ripe in August. A great bearer.

No. 7. Summer Pearmain.

This apple is of medium size, the form oblong and very regular; the skin a dark red, striped with a small proportion of yellow; the flesh very tender and good, juice not abundant. It is one of our finest Summer apples; bears abundantly; and ripens in August and September.

\section{No. 8. Rambour d'ete.}

This apple is of large size and flat form; the skin light red, striped with yellow; the flesh is firm, rich and sprightly; the trees assume a spreading form of vigorous growth and great productiveness. Ripe in September. 


\section{No. 9. Fall Harvey.}

This is a large and handsome fruit, the shape flat with broad ribs extending from the stem to the eye; the skin sometimes a clear bright yellow, but mostly a light yellow, occasionally with a bright red cheek; the flesh yellow, firm, rich and high flavored; it is much cultivated in Essex county, Mass., where it may have originated. It is without question the finest Fall and early Winter apple. A good bearer, and deserving extensive cultivation.

No. 10. Drap d'or.

A large flat apple, of a bright, but pale yellow color, covered all over with small black pips, (never with a redcheek;) the flesh is tender, very light and pleasant; the growth of the tree is large and spreading; it bears well and should be found in every good collection. Ripe in September and October. This is the Drap d'or of Cox and Ronald, but not of Duhamel.

No. 11. Hawthorndean.

This fruit is of medium size; of a flat and very regular form, and remarkably hand- 
some; skin of a pale yellow, nearly white; with a brilliant red on the side exposed to the sun; the flesh white, very juicy, but not high flavored. It bears very young and most abundantly every year; it is one of the best market fruits in the fall and early winter months.

\section{No. 12. Williams' Favourite Red.}

This apple originated in Roxbury, Mass. : it is of medium size, oblong form; the skin a bright and deep red; the flavour pleasant and agreeable. It is a good bearer and a most beautiful fruit-ripening in August.

\section{No. 13. Benoni.}

This fine and beautiful apple was introduced to notice by E. M. Richards, Esq. of Dedham. It is of medium size, form round and regular; the flesh yellow, high flavoured and excellent;-it bears well; ripens in July and August; and should be found in every good collection.

\section{No. 14. Red Doctor Apple.}

A large and handsome fruit, of a flat form ; striped and clouded with red on a yellow 
ground; the flesh is tender, breaking and high flavoured. It bears well, and ripens from October to December.

No. 15. Boxford.

This apple was first cultivated in Boxford, Essex County, where it may have originated. The size is middling, form round, skin striped with red and yellow; the flesh yellow, rich and good. Ripens in the fall months, and is thought to be a fine apple.

\section{No. 16. Red Astracan.}

This beautiful apple is of medium size, of a round and rather flat form; the skin is dark red covered with a thick bloom like a plum; the flesh is white, tender and good, somewhat acid; it keeps but a short time after being gathered, but the beauty of the fruit and its early and great bearing render it desirable in every collection, especially if intended for the market. Ripe in August.

\section{No. 17. Oslin.}

This apple is of medium size, the form flat and regular, the skin a bright yellow with 
some dark clouded spots ; the flesh firm, of a brisk and high flavour. It bears young and most abundantly, and ripens in September.

\section{No. 18. Kilham Hill.}

Originated on the farm of Doctor Kilham, in Wenham, Essex county, Mass.; the size is sometimes large, the form round, a little oblong; the skin yellow, striped with red; the flesh is yellow and high flavored, but soon becomes dry ; it bears young and constantly, and ripens from September to November. The tree is of a spreading but not regular form, and may be known by small warts or protuberances on the bark.

\section{No. 19. Lyscom.}

This apple originated in Southborough, Mass. ; it is of medium size, rather oblong, and very regular; the skin dull red with greenish yellow. The flesh is not high flavored, but of a peculiarly mild and agreeable taste. It bears well ; ripens in October, and will sometimes keep till January.

No. 20. Porter.

Originated on the farm of the Rev. Samuel 
Porter, in Sherburne, Mass. The fruit is sometimes large, the shape oblong, pointed at the blossom end; the skin of a bright yellow; often with a blush of red on the sunny side; the flesh fine, sprightly and agreeable. It bears well, ripens in September and October, and is a most beautiful fruit, either for the market or private garden.

No. 21. Duchess of Oldenburg.

A valuable and handsome apple, said to be of Russian origin. The size is middling, form round and rather flat; skin of a beautiful yellow, striped with red; flavour very pleasant and good. It bears well, and ripens in September and October.

No. 22. Yellow Ingestrie.

A beautiful apple, raised by Mr. Knight, President of the London Horticultural Society. The size is small, form round and regular; the skin of a golden yellow, with some black spots; the flesh yellow, firm and delicate. It is an abundant bearer, and ripens in October.

No. 23. Red Ingestrie.

This apple is of medium size, of a round 
form ; the skin bright yellow, tinged and striped with red on the side exposed to the sun; the flesh very rich, high flavoured and juicy. It bears well and ripens in October.

No. 24. Franklin Golden Pippen.

This apple is supposed to be of American origin ; it is of middle size, the form oval and very regular; the skin of rather a dark yellow, without a blush, but sprinkled with dark colored specks; the flesh yellow, tender and very agreeable to the taste. The tree grows well; is of an upright form, and the fruit is ripe in October and November.

\section{No. 25. Kerry Pippin.}

Fruit of medium size; the form oblong, flattened at the eye and stalk; the skin a bright yellow, striped and marbled with red; the flesh tender and high flavored. This is a most beautiful variety; it bears well, and ripens in September and October.

No. 26. Gravenstein.

Fruit large; the form for the most part oblong, sometimes flat; the skin of a light yel$\mathbf{E}^{*}$. 
low, striped and beautifully mottled with red; flesh very fine, with a brisk high flavoured juice. This is one of the most valuable apples, ripening in October, and keeping good several months. The tree is of a strong and healthy growth and upright form.

\section{No. 27. Ribstone Pippin.}

Fruit sometimes large, of a flat form; the skin is a mixture of russet and yellow, with dull red on the side exposed to the sun; the flesh very yellow and firm, with a sharp, rich flavour; the tree is of a spreading but not very regular form; it bears well, and ripens in the fall and early winter months.

\section{No. 28. Golden Russet.}

The origin of this apple is unknown ; it appears to have been first cultivated in Essex County, Mass.; the fruit is of medium size, round, rather oblong, and of a regular form; the skin is a smooth yellow russet; flesh remarkably tender, spicy and high flavoured. The tree is very upright and handsome in its growth; bears abundantly; and is a valuable fruit, ripening in October, November and December. 
No. 29. Blue Pearmain.

This fruit is large, the form round, the skin red, striped and mottled with darker red, and covered with a bloom like a plum; the flesh mild and agreeable. This is a most excellent variety. Ripe in October, and keeping till February.

No. 30. Red Quarenden.

Fruit of medium size, of a flat form ; skin a very dark red; flesh white, juicy and of a pleasant flavour. Ripe in October and November.

No. 31. Wine Apple.

Fruit large, round, sometimes oblong; the skin a bright red, striped with a little yellow, with russet round the stock; the flesh rich and pleasant; the form of the tree is spreading; it bears young and abundantly, and ripens in the autumn and early winter months.

No. 32. Fameuse.

Fruit middle size; of a flat form, skin light, yellow and green, mixt with pale red and dark red blotches on the side exposed to the sun; 
flesh remarkably white, tender, juicy and good. This is a very handsome apple. The tree bears well, and the fruit ripens from October to December.

\section{No. 33. Menagere.}

This apple is said to be of German origin; it is the largest apple we have seen; the form flat in shape like a large English turnip; the skin of a light yellow; the flesh pleasant, but more adapted to the kitchen than the dessert. It bears well trained as a dwarf, and ripens from October to February.

\section{No. 34. Rhode Island Greening.}

This is a well known and favourite apple; the size is large, the shape round, flat at the end; the color, when ripe, a greenish yellow ; the flesh yellow, tender, juicy and rich. The growth of the tree is vigorous and spreading. It bears well, and ripens from November to. February.

No. 35. Lovett Sweet:

This apple originated on the farm of $\mathrm{Mr}$. Lovett, of Beverly, Essex County, Mass.; it 
is of medium size, the form round; the skin, when ripe, a light yellow; the flesh rich, sweet and good. It is highly prized as a winter fruit.

No. 36. Murphy.

This apple in appearance resembles the Blue Pearmain ; the shape is more oblong, the size not so large; the skin light red, streaked and mottled with blotches of darker red; the flesh white, tender and good. It is in use from November to February. Raised from seed by Mr David Murphy, of Salem, Mass.

\section{No. 37. Ortley Pippen.}

The size sometimes large; the form, oblong; the skin, when ripe, a bright yellow, with a little red on the side next the sun; the flesh yellow, breaking and high flavoured, in this respect, approaching to the taste of the Newton pippen more than any other apple. The tree assumes a handsome, spreading form, bears well, and the fruit ripens from December to March. 


\section{No. 33. Newtown Spitzenburg.}

The size is large; the form round and regular; the skin a dark red, striped, streaked with shades of dull red; the flesh yellow, rich and high flavoured. A most beautiful and valuable apple; in perfection from October till February.

No. 39. White Winter Calville.

This is one of the most celebrated French dessert apples; the size is large, the form flat, with ribs extending from the stem to the eye; the skin, when ripe, of a bright yellow, sometimes with a blush of pale red; the flesh white, tender and pleasant, without being high flavored. It is an abundant bearer, and the fruit ripens from November to March.

\section{No. 40. Pennocks.}

This is a large apple; the form round, rather oblong; the skin a dull red, slightly streaked with yellow; the flesh yellow, sweet and tender; good for the table and excellent for baking. The tree grows to a large size, and forms an open spreading head. It bears well every year, and is in use during the winter months. 


\section{No. 41. Baldwin.}

This fine apple, so well known in New England, hardly needs a description. It is of medium size; the form round, the skin mostly of a brilliant red, with some indistinct yellow streaks; in some- situations a large proportion of yellow ; the flesh is very fine, crisp, juicy and rich; it bears abundantly every other year; keeps well through the winter, and although so common, it will bear comparison with the finest of the new varieties.

\section{No. 42. Lady Apple.}

The size is small, the form flat, the skin at maturity is a bright yellow, with a brilliant red cheek, and very smooth; the flesh white, breaking, mild and agreeable, but not high flavoured. The beautiful appearance of this little apple renders it worthy of cultivation. The tree is of more upright growth than any other apple tree in the orchard; it grows to a large size before it produces fruit; it then bears well, and is in use from January till March. 


\section{No. 43. Bellflower.}

This is a large and beautiful apple; the form is very oblong, tapering to the eye ; the skin a bright yellow, sometimes without any red, but for the most part the side exposed to the sun has a bright red cheek; the flesh is rich, tender and sprightly; before perfectly ripe it has too much acidity. It bears well, though not abundantly, every year, and ripens in October, and keeps till February; it is a valuable market fruit. The growth of the tree is large and spreading, and if not trained high, the branches will reach the ground when loaded with fruit.

\section{No. 44. Swaar.}

This is a large apple, the form round, somewhat flat; the skin is very smooth, of a light yellowish green, without any red; the flesh is juicy and well flavoured, but not rich. The tree is of spreading and vigourous growth; bears great crops. The fruit ripens from December to March.

\section{No. 45. Danvers Winter Sweet.}

This apple is of medium size, the form a 
little oblong, tapering to the eye; the skin smooth, of a light yellow, sometimes with a tinge of red; the flesh firm, juicy and sweet. The tree is a great bearer, of rapid growth, and is worthy of extensive cultivation. It is in use during the whole winter.

No. 46. Pickman Pippen.

This apple is sometimes large, the form round, the skin a light yellow, spotted with black points; the flesh hard, juicy and good for the table, and excellent for the kitchen, having, when cooked, a most agreeable acid. The tree is of an upright growth, bears abundant crops, and the fruit ripens from December to March.

\section{No. 47. Mela Carla.}

This apple is of medium size and round form, the skin is of a light yellow, with a bright red cheek next the sun; the flesh white, tender and good, but not rich. It is a good bearer, and ripens from October to March. In our climate this apple is not so good as in its native country, (Italy.) It is, notwithstanding, worthy of cultivation. 


\section{No. 48. Roxbury Russet.}

This apple is well known, and extensively cultivated in New England; it is of medium size, round, and flat at the ends; the skin of a fine yellow russet, often mixed with dull red; the flesh white, rich and juicy, with a very pleasant acid. It bears well, and can be brought to market later in the spring than any other good table apple.

\section{No. 49. Hubbardston Nonsuch.}

This apple is large, the form round, somewhat oblong; the skin is red mixed with a small portion of yellow, streaked and blotched with dark red; the flesh yellow, juicy, and of excellent flavour. The tree is of vigorous growth, a great bearer, and worthy of extensive cultivation. In use from January to - March.

\section{No. 50. Minister.}

This fine apple originated in Rowley, Mass: The size is large, the form oblong like the Bellflower, tapering to the eye, with broad ridges the whole length of the fruit; the skin a light greenish yellow, striped with bright 
red, but the red seldom extends to the eye; flesh yellow, light, high flavoured and excellent. This is one of the very finest apples which New England has produced. It ripens from November to February, and deserves a place in every collection of fruits, however small. This apple received its present name from the circumstance of the late Rev. Dr. Spring, of Newburyport, having purchased the first fruit brought to market.

\section{No. 51. Green Sweet.}

This apple is of small size, round, and rather flat; the skin at maturity is a dullgreen, approaching to yellow; the flesh very sweet and good. It is in use during the winter months, and can be brought to market later in the spring than any other sweet apple. Much cultivated in the north part of Essex county, Mass. 


\section{PEA R.}

No. 1. Amire Joannet.

This fruit is small, form oblong; the skin, when ripe, is light yellow, with a small portion of red ; the flesh white, and when not overripe, juicy and good. It ripens in July, about ten days before the Petit Muscat, to which it is superior in size and flavor. The head of the tree is open, with a few long and hanging branches.

\section{No. 2. Petit Muscat.}

This pear ripens immediately, after the above; the size is small; the form round, a little oblong; the skin mostly of a clear yellow, with a little dull red; the flesh pleasant and musky, without being high flavoured. The tree grows to a large size, with long and hanging limbs, producing its fruit in clusters and most abundantly.

\section{No. 3. Mudeleine.}

This is the first good pear, which ripens; immediately following the Petit Muscat; the size is 
rather small; in rich land they grow large; the skin, when ripe, is light green approaching to a yellow, sometimes a tinge of dull red on the side exposed to the sun; the flesh white, juicy and pleasant with a most agreeable acid. Ripe the end of July and first part of August; it bears well every year, and from its open head requires but little pruning.

\section{No. 4. Bloodgood.}

This pear was first brought into notice by the late James Bloodgood, of Flushing, Long Island; the size is large, the form nearly oval, the skin a dull yellow, covered with dark russet spots ; the flesh tender, melting and pleasant. It comes very early into bearing, and produces abundant crops every year. Ripe in August.

No. 5. Rousselette Hatif:

This is a small pear, with a long curved neck; the stem is long and fleshy, in most. cases appearing to be a continuation of the fruit; the skin yellow with brownish russet on the side next the sun; the flesh very fine, rich and high flavoured when eaten ripe from the $\mathrm{F}^{*}$ 
tree; the branches are long, the head of the tree very open, and the produce most extraordinary, It ripens about the middle of August.

\section{No. 6. Skinless.}

This pear is of small size, of a long shape, round at the blossom end, tapering to an obtuse point at the stem; the skin is smooth and very thin; the color when ripe is a light yellow, with a slight tinge of red; the flesh juicy, crisp, sweet and very good. The tree produces well, and the fruit ripens in August.

\section{No. 7. Summer Rose.}

A pear of medium size; the form flat, resembling an apple, with a long stem inserted in a roundish hollow; the skin is dull yellow, spotted with russet, and mixed with a large proportion of brownish red; the flesh, white, juicy and sweet, with a high and very peculiar flavor. The appearance of the tree is that of a large spreading apple tree; it grows to a large size before producing fruit; it is then very productive. Ripe in August.

No. 8. Summer Frankreal.

This very fine pear is of medium size, the 
shape oblong, thickest about one third from the eye, sometimes flat like a Bergamot. The skin when fully ripe a light yellow; flesh melting, rich and excellent. It is a great and early bearer, ripening in September.

\section{No. 9. Williams' Bon C'hretien.}

[see plate No. 1.]

This fruit is very large; the shape long, round and full, both at the eye and stem, which is short and large; the skin when fully ripe yellow, with faint red next the sun; flesh white, melting and good. The character of this pear is very high; the tree is of a strong and vigorous growth, bears very young, and yields most extraordinary crops every year. Ripe in August and September.

\section{No. 10. Julienne.}

This pear resembles the St. Michael's, but is much smaller, except on very rich land; the size is generally small; the skin light yellow, sometimes with bright red next the sun; the flesh rich, juicy and melting. The tree comes early into bearing, produces abundantly, and is in use from the middle of August to the middle of September; ripening gradually in 
the house, which renders it very desirable tor a market fruit.

\section{No. 11. Dearborn's Seedling.}

This fine and beautiful pear originated at Brinley Place, Roxbury, the seat of the Hon. H. A. S. Dearborn. The fruit is of medium size, round at the crown, diminishing to the stem, around which is a circle of bright russet; the skin is smooth, of a light yellow colour ; the flesh delicate, melting and fine flavoured, equal to any other pear of the same season. The growth of the tree is healthy and vigorous. It bears well, and the fruit ripens in August.

No. 12. Crawford.

This pear is very extensively cultivated in Scotland; it is of middle size, round at the eye, diminishing to the stem, and very regular and uniform in its appearance; the skin is entirely of a light yellow; the flesh juicy, tender and good. It bears young, and ripens in August.

No. 13. Honey.

This tree was procured from Messrs. Wm. 
Prince \& Sons, of Flushing; but as there are two pears bearing this name, one European, the other American, it is uncertain to which the specimen belonged; in size and shape it resembles the Seckle; the skin is yellow, with a large portion of dull red; the flesh sweet, juicy and good. The tree bears young, and when more advanced promises to be a great bearer. Ripe in September.

No. 14. Citron de Sirentz.

This tree was procured from Messrs. Baumans, of Bollwiller; in size, shape, colour, taste and time of ripening, it resembles the Crawford.

No. 15. Rousselette de Rheims.

This pear is of medium size, the form is oval, blunt at the stem; the skin yellow, with much dull red on the side next the sun; the flesh is breaking and fine, with a very high musk flavour; it is best when eaten ripe from the tree. The tree attains a large size before bearing; but when more advanced produces an abundant crop. Ripe in September. 
No. 16. Summer Thorn.

This pear is oblong, of medium size, the skin"smooth, and when ripe of a light green; the flesh melting, juicy and of a very peculiarly pleasant flavour. It bears well, and ripens in September.

\section{No. 17. Williams' Early.}

This new pear originated on the farm of Mr. Williams, in Roxbury, Mass. It is of middle size, turbinate form, the skin light yellow with a red cheek next the sun; the flesh melting, sugary and fine. The tree promises. to be a great bearer. Ripe in September.

No. 18. Valee Franche.

This pear in good ground is sometimes large, the form almost ffat, a little extended; the skin dull, greenish yellow and dull red; the flesh juicy, rich and pleasant. The tree bears young, is very productive, and the fruit ripens in September.

No. 19. Chair a'Dame.

This pear is of medium size, obovate, the stem is short and fleshy, obliquely inserted un- 
der some irregular bunches or protuberances ; the skin is a dull yellow, mixed with russet and a small portion of red; the flesh is crisp, coarse grained, and sugary. The tree is of vigorous growth, and appears to be a good bearer. Ripe in September.

No. 20. Green Pear of Yair.

This pear is of medium size; the form full at the crown, diminishing gradually to the stem; the skin is smooth, and when fully ripe of a light green; the flesh melting, very juicy and good. A great bearer. Ripening in September.

No. 21. St. Ghislain.

This superior pear is one of the new Flemish varieties; it is of medium size; the shape rather oblong; the skin at maturity is a pale yellow; the flesh juicy, melting and very delicious. The tree is vigorous, and bears good crops every year. One of the finest of pears, and should be found in every good collection. Ripening in September and October.

No. 22. Cushing.

A native fruit from Hingham, Mass. The 
size in rich ground is large; the form oblong, diminishing from the eye to an obtuse point at the stem; the skin when ripe smooth, of a light yellow, sometimes with dull red on the side exposed to the sun; the flesh white, melting, sprightly and good. It comes early into bearing, produces well, and the fruit ripens the last of September.

No. 23. Rostiezer.

This tree was received from the Messrs. Baumans, of Bollwiller. The fruit is of medium size, oblong and pointed at the stem, the skin covered with light yellow russet; the flesh melting, high flaroured and delicious. It ripens about the first of October, and so far as we could judge from the first specimens, is decidedly a first rate fruit.

No. 24. Jackman's Melting.

This tree was received from the Messis. Youngs, of Epsom, England ; it produced its first fruit in 1837 ; the name is no doubt erroneous, as it is not noticed in the catalogue of the London Hort. Society, or in any other work of authority. The fruit is large and 
very long, the stem short, the skin entirely of a dark red; the flesh juicy and good, but not rich ; it is remarkable for its beauty, promises to bear well, and ripens the last of September.

\section{No. 25. Seckle.}

This well known and excellent pear is of small size on poor land; the form is regular, round at the blossom end, diminishing gradually to an obtuse point at the stem; the skin often yellow with a brownish red cheek, sometimes entirely covered with greenish russet; the flesh melting and of most exquisite flavour ; the growth of the tree is slow, with great and unusual symmetry. It produces abundant crops; but in order to obtain fruit of large size, the ground should be rich and the tree pruned with a more open head, than is generally thought necessary. Ripens gradually in the house from the middle of September to the last of October.

\section{No. 26. Jalousie.}

This pear is rather above the medium size; the form round and large at the blossom end, diminishing rapidly to a point at the stem; 
the skin is smooth, and entirely covered with a cinnamon russet; the flesh white and melting, very pleasant and good. The tree bears well; and the fruit is in use during the whole month of October.

\section{No. 27. Johonnot.}

Originated in the garden of the late George S. Jolionnot, Esq. of Salem. The fruit is of medium size, of a roundish and very unequal form; a little extended, the skin thin, the colour a dull yellow, with a large portion of dull brown and indistinct russet; the flesh is very fine, melting and delicious. The tree is. not vigorous; it bears well, and is in perfection from the middle of September to the middle of October.

\section{No. 28. Andrews.}

This fruit sometimes attains a large size, the form is oblong, tapering gently from the blossom end to the stem; the skin when at maturity is a yellowish green, often with a dull red cheek; the flesh melting, juicy and high flavoured; it is a most valuable pear, prodúcing its fruit early and abundantly. The tree is not of very 
vigorous growth. Ripe in September and October.

No. 29. Autumn Superb.

This is a large pear, full and round at the eye, diminishing to a point at the stem; the skin is yellow mixed with dull red; the flesh melting and good, but not very high flavoured. It bears young and the fruit ripens in October. It was originally introduced from France, and received its present name in this country.

No. 30. Belle Lucrative.

The tree which produces this fine fruit, was received from the Messrs. Young, of Epsom, England. The size is large, the form round at the blossom end, tapering gradually to the stem; the skin, when ripe, is a pale yellow, sometimes with a little dull red next the sun ; the flesh is melting, sweet, juicy and fine flavoured. It bears well. Ripens in September and October, and is worthy of a place among the choicest selections.

No. 31. Belle et Bonne.

These trees have been received fiom vari- 
ous sources, as the Belle de Bruxelles; the fruit is large and round, the skin yellow, sometimes with a little blush on the side exposed to the sun; the flesh very sweet, rich and good. The tree is very vigorous in its growth; does not bear till it has attained a large size; it is then very fruitful. Ripe in October.

\section{No. 32. Long Green.}

This is one of the best of the old varieties; its form is very long; skin at maturity a light green ; the flesh is white, melting and fine flavoured. The tree is of vigorous growth, bears well, and the fruit ripens in September and October.

\section{No. 33. Henry Fourth.}

This pear is of small size, the form very irregular, oblong; the skin of a dull yellow, mixed with brown and green; flesh yellow, gritty, juicy and melting, with a high and somewhat remarkable flavor. It bears young and abundantly, and ripens in September.

No. 34. Beurre Van Marum.

This is one of the new Flemish pears ; it is 
of medium size, the form oblong, the skin of a bright yellow, sometimes with a tinge of red; the flesh melting, juicy and fine. It is an early and great bearer, and in perfection about the last of September.

\section{No. 35. Capsheaf.}

The origin of this pear is unknown; it is much cultivated near Providence, R. I., where it may have originated. The size is small; the form almost round; the skin a light cinnamon russet; the flesh white, melting and juicy, with a pleasant but not high flavour. It bears well, and the fruit ripens in October.

No. 36. Surpass Vergalieu.

This tree was received from the late $\mathrm{Mr}$. Parmentier, of Brooklyn, L. I. ; as we do not find the name in any European author, it was probably adopted in this country. The fruit is large, form oblong, some specimens nearly round; the skin smooth, of a light yellow with a little red on the side next the sun; the flesh rich, juicy and high flavoured. It appears to require a warm sun to have it in its greatest perfection; it bears young, yields large crops $G^{*}$ 
of fair fruit every year, and is worthy of extensive cultivation. Ripe in October.

\section{No. 37. Heathcote.}

This native pear is large on rich land; the form is long, round at the blossom end, and full at the stalk; the skin almost always of a light yellow, seldom a tinge of red; the flesh melting, rich and well flavored. The growth of the tree is handsome and vigorous. It produces abundant crops, and ripens in September and October.

\section{No. 38. Harvard.}

This pear originated in Cambridge, Mass.; the size is large, the form oblong, contracted in the middle, diminishing to an obtuse point to the stem, which is inserted in a small cavity ; the skin is of a dull russety yellow, sometimes nearly covered with brownish red; the flesh white, juicy and fine, but subject to rot at the core, which is its only defect. The tree is uncommonly strong and upright in its growth ; it attains a large size before producing fruit; it is then a great bearer. Ripe in September and October. 


\section{No. 39. Naumkeag.}

This is a seedling from the garden of the late G. S. Johonnot, Esq., of Salem ; the wood and leaf of the tree resemble those of the Brown Beurre. The fruit is large, form oval, rather oblong, full and round both at the blossom end and at the stem; the skin a yellow russet, with much dull brown mixed with russet; flesh juicy, melting and good, with rather too much astringency. A great bearer,-ripening in October.

No. 40. Raymond.

A new fruit, which originated on the farm of Doctor Joseph Wight, of Raymond, Me. It is sometimes large, but generally of a medium size, the shape of the St. Michael's ; the skin yellow with some dull red and russet on the side exposed to the sun; the flesh melting, rich and high flavoured, equal to any pear of the same season. The tree is slow and crooked in its growth, but produces well, and the fruit ripens in September and October.

\section{No. 41. Buffum.}

This pear originated in Rhode Island; the 
size is large, the form nearly oval, the skin yellow mixed with russet and brownish red next the sun; the flesh melting and good, but not first rate. The tree is very upright and strong in its growth; a great bearer, and an excellent market fruit. Ripe in September.

\section{No. 42. Beurre Bosc.}

One of the new Flemish pears; the form is very long, the skin of a light cinnamon russet; the flesh white, juicy, melting and good. It bears abundantly, and ripens in October and November.

No. 43. Golden Buerre of Bilbua.

This tree was imported from Bilboa, by Mr. Hooper, of Marblehead; the original name is unknown; in size and shape it resembles the Doyenne Gris, but the skin is of a lighter russet; the flesh is melting, rich and of fine flavour ; it promises to be a good bearer. Ripens in October.

\section{No, 44. Washington.}

A native fruit from New Jersey, of medium size; the form is oval, the skin of a light 
yellow, covered with small brown spots, sometimes a slight tinge of red; the flesh melting and excellent, with an unusual flavour. The tree grows vigorously, bears well, and the fruit ripens in September. A beautiful and good pear, worthy of cultivation.

\section{No. 45. Gansels Bergamot.}

This has been placed among the old pears; it is only comparatively so, having been raised in 1768 ; as yet it shows no indication of decay, such as we see in many of the finest old pears. It has the reputation of being a bad bearer, but in the gardens in Salem it produces good crops. The fruit is of medium size, the form nearly round, the colour a dull brown ; flesh white, melting and fine flavourcd. Ripe in October.

\section{No. 46. Cabot.}

This pear was produced from seed by Joseph S. Cabot, Esq., of Salem; the original tree, after producing the first specimen of fruit, was destroyed by the cold winter of 1831 ; we were so fortunate as to preserve a scion, from which we obtained fruit the last 
season, 1837. It is of medium size, of a round form, a little extended; the skin a light yellow russet, with a small portion of brownish red; the flesh white, melting and fine fiavored. It is decidedly a first rate fruit, and worthy of extensive cultivation; the tree is of a strong and healthy growth, bears well, and is in perfection during the whole month of October.

\section{No. 47. Pope's Quaker.}

The origin of this pear is uncertain; it appears to have been first cultivated by a Mr. Pope, a nurseryman near New York; the fruit is of medium size, oblong pear shaped, the skin entirely covered with yellow russet; the flesh white, melting and good, but not high flavoured; the tree is productive. The fruit ripens in Qctober.

No. 48. Bon Chretien Fondante.

This is one of the new Flemish pears; fruit rather large, form regular, oval; the skin a yellowish green, mixed with brown and yellow specks; the flesh yellow, rich and melting; the tree produced fruit the first time, the 
last season, 1837, and promises to be a first rate fruit. Ripe in October.

\section{No. 49, Princess of Orange.}

One of the new Flemish pears. In size and form this fruit resembles the St. Michael's; the skin is an orange russet, mixed with dull red; the flesh white, melting and good, but not first rate. Ripe in October. The scions of this pear were originally received from the London Horticultural Society, but a distinguished cultivator of fruit from Belgium, thinks it cannot be the Princess of Orange of Van Mons.

\section{No. 50. Cumberland.}

A native fruit from Cumberland, R. I.; the size is large, the form oblong, round and large at the blossom end, tapering to an obtuse point at the stem; the skin of an orange colour, with bright red next the sun; the flesh melting, juicy and good, nearly first rate. Ripe in October and November. The tree is of vigorous growth, and bears abundantly.

No. 51. Louise Bonne de Jersey. Fruit large oblong, pear shape; skin yel- 
lowish green, mixed with brownish red next the sun; the flesh melting, rich and good. It produced its first fruit the last season, and gives every indication of being a first rate pear, and good bearer. Ripe in September and October.

No. 52. Reine des Poires.

This is a large pear; the form obtusely pyramidal; the skin a dull yellow mixed with red, and red on the side exposed to the sun; the flesh crisp, pleasant and good, but not high flavoured; it bears young, and is very productive. Ripe in October. The tree has a great resemblance to that of the Easter Beurre.

No. 53. Petre.

This tree was presented to me by Mr. Carr, of the Bartram Botanic Garden, near Philadelphia, where the fruit originated. The first specimens were produced the last season, 1837. The size is large, the form long, round at the eye, and tapering to an obtuse point at the stem; the skin is a dull yellow, mixed with greenish russet; the flesh melting, juicy, 
and very delicious. Ripe in October and November. It is a pear of the very first rank, and should be extensively cultivated.

No. 54. Frederic of Wurtemberg.

This is one of the new Flemish pears, and has been cultivated under the erroneous name of the Capiaumont. The size is large, round and full at the blossom end, tapering rapidly to a point at the stem, which is short and placed on the summit; the skin a bright yellow, with a brilliant red cheek next the sun; the flesh yellow, melting, rich and excellent. The tree grows vigorously, bears young and abundantly, and the appearance of the fruit is beautiful. Ripe in September and October.

\section{No. 55. Urbaniste.}

One of the new Flemish pears, the size and form is somewhat like the St. Michael's, round and full at the eye, diminishing gradually to an obtuse point at the skin, which is inserted in a shallow round cavity; skin light green, nearly yellow, with small spots of dull russet ; flesh white, melting and fine. The tree is of handsome form and grows vigorously; does 
not bear young, but is productive after it has attained a proper size. Of all the new European pears, this is the best substitute for the old favorite, St. Michael's. Ripe in October and November.

\section{No. 56. Wilkinson.}

A native pear from Cumberland, R. I.; the size in rich ground is large, the form oblong, round at the blossom end, and at the stem; the skin yellow, seldom (on pear stocks) any red; the flesh white, juicy and melting, with a fine and delicious flavour. The tree bears young, is very fruitful, and in perfection during the months of October and November. If grafted on the quince it is smaller, more prolific, higher flavoured, and a brighter red cheek, than if grafted on the pear stock.

No. 57. Bergamotte d'Automne.

This pear is of medium size, the form round, a little lengthened towards the stem, which is short and inserted in a small cavity; the skin when ripe is a dusky yellow, thickly sprinkled with greyish spots; the flesh breaking, tender, juicy and sweet. It is a good fruit, an 
early and great bearer, ripening gradually in October; distinct from the Autumn Bergamot described by Cox, and figured in the Pomological Magazine.

\section{No. 58. Napoleon.}

One of the new Flemish pears; the size is large, the form long, round at the blossom end, contracted in the middle, obtuse at the stem which is short; the skin at maturity is a yellowish green; flesh melting and fine, with an unusual quantity of juice; in some soils a little too astringent; tree healthy and strong, bears well, and the fruit ripens in October.

\section{No. 59. Marie Louise.}

This is also one of the new Flemish pears; the size is large, the form long, tapering from the middle to the eye and stem; the skin is a dusky yellow, sometimes with a large portion of cinamon russet; the flesh white, melting, juicy and very delicious ; the tree grows crook$\mathrm{ed}$, and the leaves are small and generally hollowed like the bowl of a spoon; it is equal to any other pear of the season, European or American. Ripe in October and November. 


\section{No. 60. Fulton.}

This pear originated on the farm of Mrs. Fulton, Topsham, Me. ; the size is small, the form nearly round, a little lengthened, the skin entirely covered with dark russet; the flesh white, melting, juicy and well flavoured; the tree bears well, and the fruit ripens gradually in the house, in October and November.

No. 61. Bleeker's Meadow.

A native fruit from New York; the size is small, the form round, somewhat flat; the skin, when fully ripe, is yellow; the flesh yellow, melting, juicy and very high flavoured. The growth of the tree is vigorous; it does not bear young, but as it increases in size it bears well. A fine delicious pear, ripening in October and November.

\section{No. 62. Dix.}

This fine pear originated in the garden of Mrs. Dix, in Boston; the size is large, oblong, tapering gently from the blossom end to the stem, which is short; the skin, when ripe, is yellow, sometimes with a blush of red on the side exposed to the sun; the flesh melting, 
juicy and very rich, with a high and most agreeable flavour; in perfection during the months of October and November; the tree is of slow growth, the wood small and thorny ; it grows to a large size before bearing; it then produces plentifully.

No. 63. Duchesse d'Angouleme.

One of the new European pears; the size is very large, oblong, round at the blossom ends, tapering gradually to an obtuse point at the stem with a knobby and uneven surface; the skin greenish yellow, spotted with small russet points; the flesh very rich, melting and high flavoured. It is a good pear on standards in rich ground, larger and better on the quince, trained low; it is very productive. Ripe in October and November.

No. 64. Moorfoul's Egg, of Boston.

A pear of medium size, oval form ; the skin light green, mixed with russet and brown next the sun; the flesh tender, juicy and good; tree of vigorous growth, and ripens in November. This we think cannot be the pear of the same name cultivated in England and Scotland. 


\section{No. 65. Beurre Diel.}

One of the best of the new Flemish pears; the size is very large, tapering gradually from the middle to both the eye and stem, where it is full and thick; the skin when ripe of an orange colour, with small russet spots; the flesh white, sugary, rich and delicious; the tree is of a crooked, but strong and healthy growth ; it bears well, and the fruit ripens in November and December.

No. 66. Sylvanche Verte.

The pear which we cultivate by this name resembles the Beurre Diel, in size, shape, colour, flavour, and time of ripening; the growth of the tree is also similar, at least we can perceive no difference. We see by the 2d Edition of the London Hort. Society's Catalogue, that this pear had not then been proved in their garden.

No. 67. Bourgmestre, of Boston.

A pear of large size, very long, round at the blossom end, tapering gently to a point at the stem, which is short and fleshy at its junction with the fruit; the skin greenish yellow, (on 
a quince stock it has a bright red cheek;) the flesh juicy and pretty good, but not rich. Ripe from. November to January. This is not the Bourgmestre of the London Hort. Society's Catalogue. We were inclined to discontinue its cultivation, but its abundant bearing, great size, and beautiful appearance, the two last seasons, have induced us to continue it for further investigation.

\section{No. 68. Newtoun Vergalieu.}

We should judge by the name that this pear originated on Long Island; it is of large size, round at the blossom end, tapering to a point at the stem, which is short; the skin of a pale yellow, seldom with a tinge of red; the flesh is sweet, rather dry, not highly prized as a table fruit, but excellent for baking. It ripens in the early winter months, and its productiveness renders it desirable in an orchard. The tree is crooked and strong in its growth, forming a large spreading head like that of an apple tree.

No. 69. Fig Pear of Naples.

The scions of this pear were received from 
the London Horticultural Society. In their catalogue it is described as first rate; the fruit is of large size, form oval, skin a dark brown, with a mixture of red; flesh melting, juicy and good; it is very productive, and bears young. Ripe in November and December.

\section{No. 70. Winter Nelis.}

One of the new Flemish pears; the size and form is somewhat like the Seckle; the skin a greenish yellow, covered with dark spots; in some seasons they have a large portion of dull russet; the flesh yellow, melting, sweet, and very high flavoured; a very fine pear, ripening during the months of December, January and February.

\section{No. 71. Passe Colmar.}

This is also one of the new Flemish pears; the size is large, the form round and full at the blossom end, contracting suddenly to the stem, which is about an inch long, and planted in a small and oblique cavity; the flesh is yellow, melting, sweet and excellent. The growth of the tree is vigorous, without any 
symmetry; its produce very great; it is a favourite, and deserves to be so. We have had them in eating from October to February.

No. 72. Surpasse St. Germain.

Introduced into England from Flanders, by the late John Braddick, Esq. It is of medium size, round at the crown, tapering to the stem, which is obliquely planted; it is of very irregular form; the skin is rough, yellow mixed with dull brown; the flesh coarse grained, sugary and high flavoured; it produces abundantly, and the fruit ripens in December and January.

No. 73. Lewis.

This pear originated on the farm of $\mathrm{Mr}$. John Lewis, Roxbury, Mass. The size is small, the form round, a little oblong; the skin, when ripe, a greenish yellow; the flesh white, melting, juicy and good. The tree is of the most rapid growth; a great and constant bearer. The fruit ripens from November to February.

No. 74. Prince's St. Germain.

Produced from seed at the Nursery of W. 
Prince \& Sons, at Flushing, L. I. The fruit is of medium size; in form sometimes like the old St. Germain; the skin yellow, with patches of russet, and a dull red cheek on the side exposed to the sun; the flesh is melting and good, but not esteemed a first rate fruit; its abundant bearing, and its ripening gradually in the house during the winter, renders it a very valuable market fruit.

\section{No. 75. Glout Morceau.}

A new Flemish pear; the size is sometimes large, the form rather oblong, round at the crown, diminishing suddenly to the stalk, which is inserted in an oblique cavity; the skin is a dull green, nearly yellow when ripe, mixed with russet blotches; the flesh white, juicy and excellent; the growth of the tree is crooked and bending; it produces well, and the fruit ripens gradually from December to February. The French nurserymen still continue the cultivation of this pear under the name of the Beurre d'Aremberg.

\section{No. 76. Echasserie.}

This is one of the old French table pears ; 



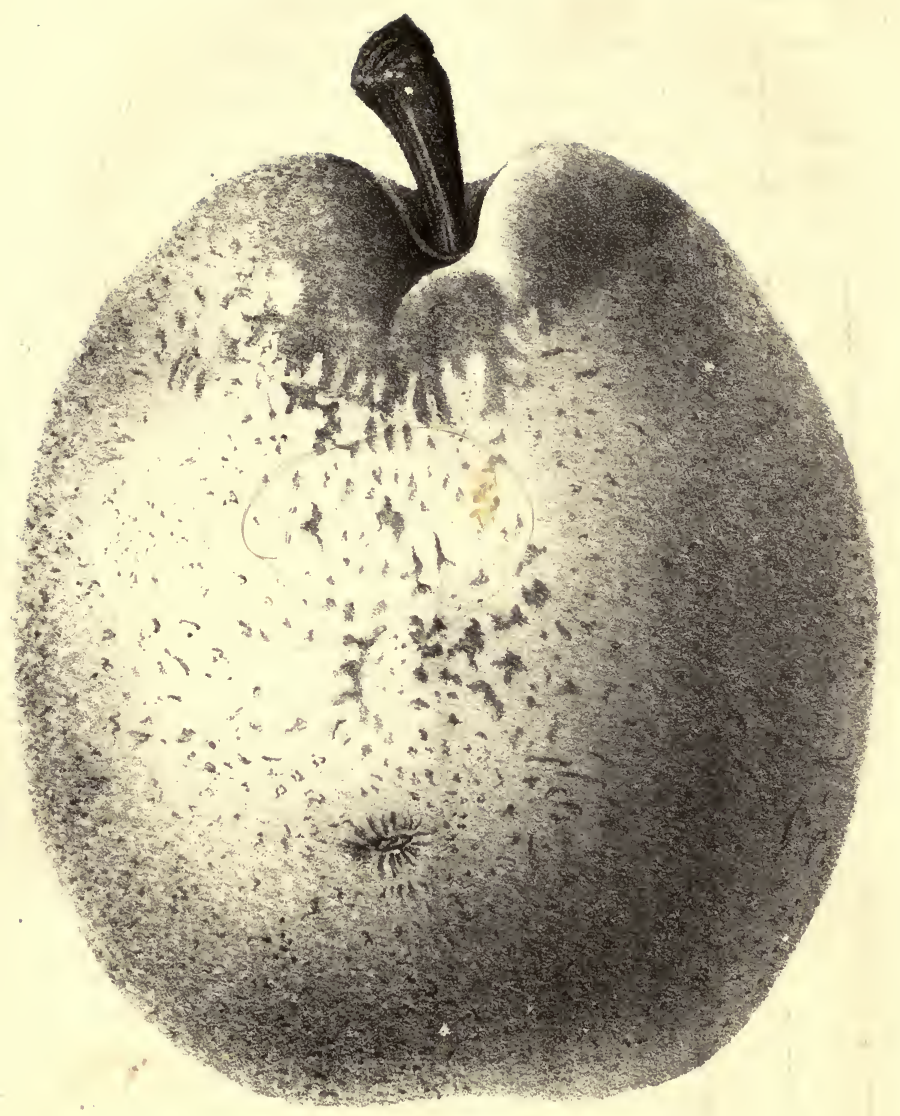

Mamisis 1. the lis

Enster Bunrré Pear. 
the size is small, of oval form; the skin, at maturity, a greenish yellow; the flesh melting, juicy and sugary. It is a good bearer, and a favourite winter pear, ripening from December to March.

\section{No. 77. Beurre d'Aremberg.}

A new Flemish pear; in good ground it is usually of a large size ; the form oblong, thick at the crown and stalk; the skin when ripe a dark yellow mixed with russet specks; the flesh white, melting, rich and sweet. It is in eating during the winter months, and has the reputation of being one of the most valuable table pears.

\section{No. 78. Easter Beurre.}

[See plate No. 2.]

The size of this pear is large; of an oval form; the skin, when ripe, is dark yellow, covered with russet spots; the flesh yellow, melting and high flavoured. It bears abundant crops, grafted either on the pear or quince; keeps till May, and is the most valuable late winter pear yet known.

\section{No. 79. Catillac.}

This is one of the old French baking pears; 
it is very large, flat and round at the crown, diminishing rapidly to the stalk, which is an inch in length, obliquely inserted; the skin of a light green, nearly yellow when ripe; the flesh hard and suitable for baking from November till April;-very productive.

No. 80. Black Pear of Worcester.

Fruit large, oblong; skin rough, covered with dull russet; the flesh hard and coarse, suitable for baking during the winter and spring; it produces abundantly; the branches of the tree, when loaded with fruit, bend to the ground like the weeping willow.

No. 81. Pound Pear.

This is one of the largest pears; its origin unknown, but supposed to be European; the form oblong; some of the pears are thickest in the middle, tapering to the crown and stem; the flesh coarse and astringent. It is a great bearer, and the best winter baking pear, being one of the most profitable fruits for the market. The extensive cultivation of Nos. 79, 80 , and 81 , in large orchards, would produce greater and surer income, for the capital employed, than any other investment. 


\section{P EACIS.}

\section{No. 1. Early Ann.}

This is a small round fruit, with a greenish white skin; flesh melting and good. The tree does not attain a large size; a freestone, ripe in August.

\section{No. 2. Early Royal George.}

The size is large, the form round, the skin of a bright yellow, with a large portion of deep red on the side exposed to the sun, the flesh melting and delicious; it is a great bearer, and one of the most superior peaches we have ever raised; a freestone, ripe in August.

No. 3. Red Rareripe.

This is a large freestone peach ; form nearly round; the skin of a very bright yellow, with a light red cheek; the flesh very rich and excellent. Ripe in August.

No. 4. White Rareripe.

This peach is of large size, the form somewhat oblong, the skin a pale yellow, nearly 
white; flesh white, juicy and of fine flavour. Ripe in August.

No. 5. Red and Yellow Rareripe.

A large round freestone peach; the skin of a decp orange yellow, with a dark red cheek; the flesh deep yellow, rich, sweet and luscious. The tree is an abundant bearer; and a most valuable peach-ripening in August.

\section{No. 6. Grosse Mignonne.}

'This a large, round and most beautiful freestone peach; the skin deep yellow, with a brownish red cheek next the sun; flesh light yellow, fine and delicious. $A$ peach of the highest character. Ripe in August.

\section{No. 7. Red Cheek Melacoton.}

A large freestone peach, of an oblong shape, the skin of an orange yellow, with a dark red cheek; flesh yellow, melting and rich. Ripe in September.

\section{No. 8. Malta.}

This peach is of a large size; form round, rather flat at the stem; the skin a light green, 
mottled and blotched on the sumny side with dull red; the flesh greenish yellow, red next the stone, with' a most superior flavour; a freestone peach. Ripe in September.

\section{No. 9. President.}

A large and most superior freestone peach; the form roundish oblong; the skin pale yellow with a bright red cheek; the surface covercd with small red spots, which give it a rich and beautiful appearance; the flesh white and high flavoured; one of the best of peaches. Ripe in September.

\section{No. 10. Belle de Vitry.}

This peach is of large size; the form round, a littie obluñ ; the skin a dull yeilow and red; the flesh melting, juicy and excellent; between a freestone and clingstone. Ripe in September.

\section{No. 11. White Blossum.}

Of medium size, oblong; the skin a very light yellow, nearly white; the flesh white, melting and extremely juicy, with a most agreeable acidity. ' Ripe in September. IVe 
have found this a hardy peach, and most certain bearer in our climate. We have for several years reproduced them from the stone. The blossoms are clear white, and the young wood resembles that of the willow tree.

\section{No. 12. Orange Freestone.}

This peach is of medium size; the form round; the skin a deep orange yellow; flesh yellow and sweet, but rather dry; a beautiful and good fruit. Ripe in September.

\section{No. 13. Congress Clingstone.}

The size is large, form round; skin yellow and bright red; flesh rich and excellent. Ripe in September.

No. 14. Otdmixon Clingstone.

Large, round and rather flat; skin whitish yellow, with a bright red cheek, beautifully spotted with red dots. Of all the clingstone peaches this is the most delicious; a great bearer, ripening its fruit gradually in September. We have cultivated this peach, and the Catharine and old Newington, and could never perceive any difference in the fruit or trees. 



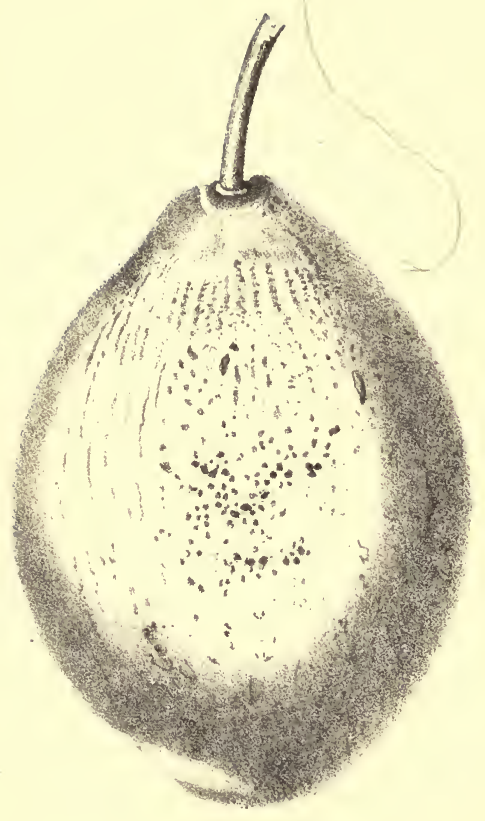

Moore's Lith. Boston

Coe's Gozden Drop Plum 
No. 15. Heath Clingstone.

Fruit large, oblong ; skin of a delicate cream colour, sometimes with a faint blush on the sunny side; flesh rich, very juicy and fine flavoured. Ripe in October, and we have eaten them produced in our own orchard in the highest perfection, on Thanksgiving Day, November 30 th.

The Nectarine and the Apricot, so nearly allied to the Peach, we should not recommend for cultivation upon standards, but inoculated upon the plum stock, and trained as Espaliers upon walls or fences, they often produce fine fruit, particularly the Apricot.

\section{P I U INES.}

No. 1. Italian Damask.

Fruit of medium size, round; skin dark blue, nearly black; stem half an inch long, inserted in a small round cavity; flesh yellow, juicy and high flavoured. A freestone, a great bearer, and one of the best early plums. Ripe in August. 


\section{No. 2. Morocco.}

A fine and very productive variety ; the size is rather small, nearly round; the skin a dark purple, covered with a blue bloom; flesh greenish yellow, juicy and good. A clingstone-ripening in August.

\section{No. 3. Prince's Imperial Gage.}

Originated at the Nursery of Wm. Prince \& Sons, Flushing, N. Y. Fruit nearly as large as the yellow egg plum; of an oval form; when fully ripe the skin is yellow, with streaks of bright yellow and green indistinctly seen ; the flesh rich and sweet. The most productive and profitable of all the plums. Ripe in August.

No. 4. Brevoort's Purple Washington.

Produced from the stone of Bolmar's Washington, by Mr. Brevoort, of New York. ' Fruit of large size; form round, and nearly oval ; skin dark blue, covered with a blue bloom; the flesh sweet and good. A freestone, ripening in September. 'The tree is of vigorous growth and very productive. 


\section{No. 5. Orleans.}

This is a well known and productive plum; the fruit is sometimes large; the form round; the skin dark, approaching to a purple, with a thin blue bloom; the flesh yellow, firm and good, with some astringency near the stone, from which the flesh separates. Ripe in August.

\section{No. 6. Kirk's Plum.}

Fruit large, round; skin dark purple, covered with a dense bloom, which adheres firmly to the skin; flesh yellow, juicy and rich. A very productive freestone plum-ripening in August.

\section{No. 7. Purple Gage.}

Fruit of medium size, nearly round, a little flattened at the ends; skin of a violet colour, with a light blue bloom; the flesh greenish, rich and high flavoured. A first rate freestone plum; a great bearer. Ripe in August.

\section{No. 8. Large Long Blue.}

The origin of this fine plum is uncertain; the tree which produced the specimens was 
procured from the Nursery of the Messrs. Landreth, Philadelphia. The size is large; the form oval, very long; the skin blue, nearly black, covered with a thick bloom; the flesh yellow, rich and excellent; it hangs a long time on the tree, ripening gradually, and is well adapted to the market, bearing carriage better than most other plums. It is a great bearer; a freestone. Ripe in September.

\section{No. 9. Green Gage.}

The finest of all plums; of medium size, round; the skin a greenish yellow, when very ripe nearly yellow, mottled with red near the stem; flesh sugary and of delicious flavour. In our own exposed grounds, and in grass, it bears abundant crops, not being subject to rot like many fine plums. A freestone, ripening in August and September.

\section{No. 10. Bleeker's Gage.}

Produced from seed by the Rev. Mr. Bleeker, of Albany, N. Y. The form oval, nearly round; skin a dark yellow, with dark red spots and blotches; the flesh is rich and excellent. A great bearer. Ripe in September. 


\section{No. 11. Cuoper's Plum.}

Produced from a stone of the Orleans, by Mr. Joseph Cooper, of New-Jersey ; the size is very large, round, a little oblong; the skin a dark purple; flesh greenish yellow, rich and good. It ripens in September; produces abundant crops ; but is very subject to rot at the period of ripening.

\section{No. 12. Elfrey.}

This is a plum of small size and oval form; the skin dark blue; the flesh dry, firm and of fine flavour. The trees produce abundantly. A freestone-ripening in September.

\section{No. 13. German Prune.}

Fruit of medium size; form oval, diminishing towards the stem; the skin purple with a blue bloom; the flesh rich, sweet and delicious. It produces abundantly ; it begins to ripen in August, and can be eaten from the tree for a month or more.

\section{No. 14. Duane's Purple.}

This is a plum of an extraordinary size; the form round; the skin a dark purple; 
flesh sweet and good. The origin of this plum is uncertain; it ripens in September, and has the reputation of being a fine fruit.

\section{No. 15. Bingham.}

Fruit large; the form oval; skin a bright yellow, spotted and blotched with red; the flesh yellow, rich and delicious. A clingstone-ripening in September.

\section{No. 16. Washington.}

This very superior Plum originated in NewYork; the size is very large; form oval; skin an orange yellow, speckled with red; the flesh yehiow, sweet and excellent; highly esteened as a first rate plum. Ripe in Sep̃tember.

\section{No. 17. Italian Prune.}

The size is large; form oblong; the skin dark purple, covered with a bloom; flesh greenish yellow, firm, dry and finc. It bears well, and the fruit ripens in September and October.

\section{No. 18. Diamond.}

This new plum originated in England; it 
is of the largest size, oblong; the skin purple, nearly black, covered with a thick bloom; the flesh firm and good, but not rich; the tree is of rapid growth-an extraordinary bearer. The fruit ripens in September.

\section{No. 19. Blue Imperatrice.}

Fruit of medium size; shape oblong, tapering to the stem; the skin a dark purple, covered with a light bluish bloom; the flesh yellowish green, firm, rich and sweet. A clingstone. A great bearer. It hangs on the tree a long time, and is in use in October and November.

No. 20. Coe's Golden Diop. [See plate No. 3.]

This beautiful new plum is of large size; the form is oval, with unequal sides; the skin a golden yellow, spotted with rich red points and small blotches, on the sunny side; the flesh yellow, sweet and delicious. A clingstone-an abundant bearer. Ripening gradually in September, October and Novenber. Of all the late plums this is decidedly the best and the most profitable which can be cultivated. 


\section{FIIRIES.}

No. 1. Mayduke.

Fruit of medium size, round; the skin when fully ripe very dark red; the flesh tender, juicy and good. It is very productive, and the fruit ripens the last of June.

\section{No. 2. Davenport's.}

This fine cherry originated on the farm of Mr. Davenport, in Dorchester, Mass.; the fruit is large, skin bright red; the flesh firm and of excellent flavour. It is an early and most extraordinary bearer. Fruit ripe early in July.

No. 3. Black Tartarian.

[See plate No. 4.]

One of the finest and most productive cherries; the size is large, heart shaped, the colour when fully ripe is black; flesh dark red, tender and of superior flavour. Ripe early in July.

No. 4. Napoleon Bigarreau.

The tree of this variety is remarkable for 


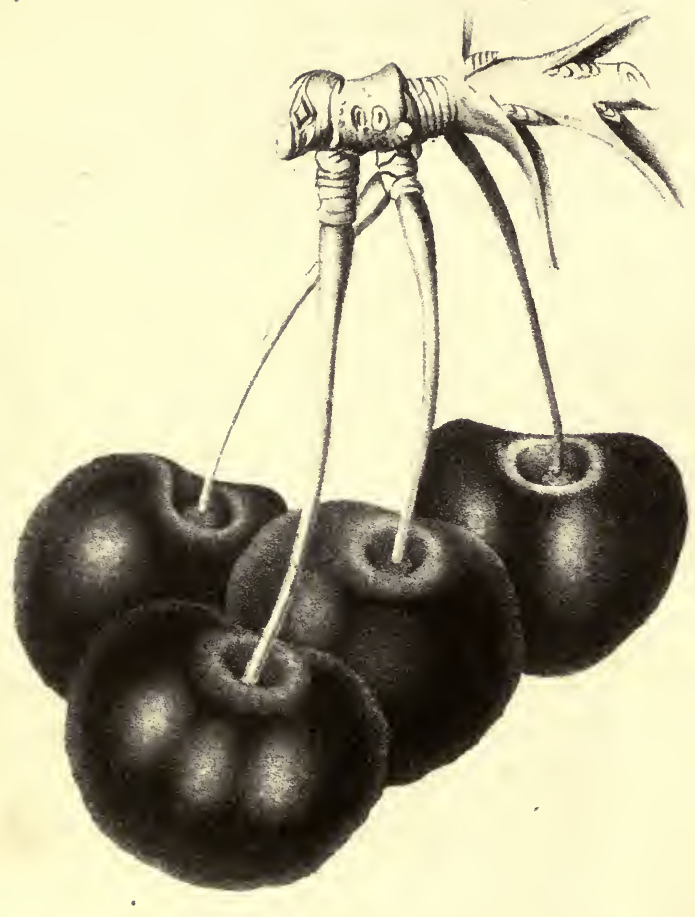

Buerais terti, is

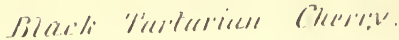



the vigor and beauty of its growth; the leaves are large and smooth. It is a fine large white cherry, ripening in July. As they have just come into bearing upon small trees, we cannot as yet say how productive they may be.

\section{No. 5. Black Heart.}

A well known and favourite cherry, of medium size, the skin when at maturity is black; flesh dark red, tender and of fine flavour. Ripe in July. Very productive. We seldom see this cherry brought to market perfectly ripe; when suffered to remain on the tree till they have acquired their proper colour, they are very superior.

\section{No. 6. Florence.}

This cherry resembles the white Bigarreau; but is a little more oblong; the flesh more tender, and ripens a few days earlier; very fine and productive.

\section{No. 7. Elton.}

A new and very fine cherry, raised by $\mathrm{Mr}$. Knight, President of the London Horticultural Society; it is of medium size, long heart 
shape; of a beautiful cream colour, marbled with bright red next the sun; flesh rich and excellent. It is ripe about the first of July, and promises when the tree has attained a proper size, to be a great bearer.

\section{No. 8. White Bigarreau.}

One of the largest and finest cherries; the form obtuse, heart shaped; skin pale yellow, with a bright red cheek ; flesh very firm, juicy, sweet and fine flavoured. Ripe in July. This cherry has the reputation of being a bad bearer. In our orchard it bears abundantly, and owing to the hardness of its flesh, is not liable to injury from birds; on this account it is highly deserving of cultivation.

\section{No. 9. Black Eagle.}

This is a new cherry; the size is sometimes large, shape nearly that of the black heart; skin a very dark purple; flesh tender, of superior flavour; the young trees bear well. Ripe in July.

No. 10. Gridley.

Originated on the farm of Mr. Gridley, in 
Roxbury, Mass. Fruit of medium size, nearly round; skin black; flesh firm, rather dry, of good flavour, and a most abundant bearer. Ripe in July.

\section{No. 11. Downer.}

This fine cherry originated in the garden of Samuel Downer, Esq. in Dorchester ; it is a large, round cherry, of a light red colour; flesh firm and of a fine sprightly flavour. It ripens in July, and is very productive.

\section{No. 12. Late Duke.}

The size is large; heart shape, rather flat; the skin a shining dark red; flesh tender, juicy and good. It is a great bearer. Ripe late in July.

\section{No. 13. White Mazzard.}

A new fruit, which originated in the Pomological Garden, from a stone of the White Bigarreau; it is of the size, form and colour of the Elton; the tree is of a handsome and upright growth, and bears well. Ripe in August. 


\section{No. 14. Plumstone Morello.}

This is the largest and finest of the acid cherries; the skin is very dark red, when fully ripe it is nearly black; flesh dark red and of a sharp, rich and agreeable flavour. A great bearer; it remains late on the tree in a sound state. 


\section{HARDY ORINAMTNTAI TREIS \& SHRUBS.}

The Catalogues sent out from the different Nurseries in our country contain many Trees and Shrubs which are in fact not suitable for New-England culture, as our winters are so severe that they are often killed to the ground;-such are the Rhus cotinus or Venitian Sumache, the Ailanthus or Tree of Heaven, Osage Orange and frequently the Catalpa ;-we have therefore selected the following list, of those which can be recommended as hardy and will stand our winters unprotected, commencing with

\section{Large Ornamental Trees-Class 1.}

Abele, or Silver Leaf-White Ash-Button Wood-Horse Chesnut-Weeping WillowButternut-Scotch Larch-Do. Elm-Lime, or Linden-American Larch-Common Locus t-Honey do. or 3 thorn'd Acacia-Scarlet maple-Sugar do.-Black and Red Spruce, Silver or Balsam Fir-(both Evergreens) - Liriodendron, or Tulip Tree-European Sycamore-Striped leaved Sycamore.

$$
\mathbf{J}^{*}
$$


Small Ornamental Trees-Class 2.

Siberian Red and Yellow Crab-Curled Mountain Ash-Weeping do.-Double Flowering Cherry-Snow Drop or Fringe TreeFranklinia-Kentucky Coffee Tree-Laburnum-Double Flowering Peach-Shepardia, or Buffalo Berry.

Shrubs, Vines and Trees of Low GrowthClass 3.

Rose Acacia-Double Flowering AlmondAltheas, (the Double White excepted) - Calycanthus (Carolina Alspice) - Caucassian Honeysuckle-Missouri Fragrant Currant-Cornelian Cherry, (Cornus)-Tartarian Honeysuckle-English Fly do. (Vine)--Fragrant Monthly do. (Vine)-Scarled Trumpet do. (Vine)-Privit or Prim-Persian Lilac-Japan Quince or Pyrus Japonica_Snow Ball or Guelder Rose-Tree Pæonias, various kindsJapan Globe Flower (blossoms twice in the season)-Snowberry :- -and nearly all the varieties of Rose, with the exception of the Chinese Monthly Roses, (so called,) which require protection during the winter. 
GOOSEBRRIIES.

In the article already given upon this fruit we recommended sending for those (without regard to names) "which have been tested by the Nurseryman and proved to be the best flavoured." The following list of good kinds of the Scotch and Lancanshire varieties, from a grower of this fruit, we subjoin on his authority.

\section{Red Fruit.}

Small Sorts. Red Champagne-Rough Red-Scotch Best Jam.

Larger Sorts. Boardman's-Keen's Seedling-Leigh's Rifleman-Farrow's Roaring Lion-Red Warrington.

\section{White Fruit.}

Small Sorts. White Crystal-White Champagne-Early White-White Honey.

Larger Sorts. Woodward's WhitesmithWellington's Glory-'Taylor's Bright Venus-Coleworth's White Lion-Saunders' Cheshire Lass.

\section{Yellow Fruit.}

Small Sorts. Yellow Champagne-Early Sulphur--Rumbullion-Hepburn Yellow Aston. Large Surts. Dixon's Golden Yellow. 


\section{Green Fruit.}

Small Sorts. Early Green Hairy--Hepburı Green Prolific--Glenten Green--Pitmaston Green Gage.

Larger Sorts. Collier's Jolly AnglerEdwards' Jolly Tar.

In closing this first manual, we here subjoin an extract from Lindley, one of the most celebrated modern writers on Pomology, on the method of producing new varieties of fruit. He says, -

"The power of procuring intermediate varieties by the intermixture of the pollen and stigma of two different parents is, however, that which most deserves consideration. We all know that hybrid plants are constantly produced in every garden, and that improvements of the most remarkable kind are yearly occurring in consequence. Experiments are, however, it may be supposed, sometimes made without the operator being exactly aware of either of the precise nature of the action to which he is trusting for success, or of the limits within which his experiments should be confined. 
"Cross fertilization is effected, as every" one knows, by the action of the pollen of one plant upon the stigma of another. The nature of this action is highly curious. Pollen consists of extremely minute hollow balls or bodies; their cavity is filled with fluid, in which swim particles of a figure varying from spherical to oblong, and having an apparently spontaneous motion. The stigma is composed of very lax tissue, the intercellular passages of which have a greater diameter than the moving particles of the pollen.

"When a grain of pollen comes in contact with the stigma, it bursts and discharges its contents among the lax tissue upon which it has fallen. The moving particles descend through the tissue of the style, until one, or sometimes more, of them finds its way, by routes specially destined by nature for this service, into a little opening in the integuments of the ovulum or young seed. Once deposited there, the particle swells, increases gradually in size, separates into radicle and cotyledons, and finally becomes the embryo,that part which is to give birth, when the seed is sown, to a new individual. 
"Such being the mode in which the pollen influences the stigma and subsequently the seed, a practical consequence of great importance necessarily follows, viz. that in all cases of cross fertilization the new variety will take chiefly after its polliniferous or male parent; and that at the same time it will acquire some of the constitutional peculiarities of its mother.

" Thus, the male parent of the Downton Strawberry was the Old Black, the female a kind of Scarlet; in Coe's Golden Drop Plum, the father was the Yellow Magnum Bonum, the mother the Green Gage; and in the Elton Cherry the White Heart was the male parent, and the Graffion the female.

"The limits within which experiments of this kind must be confined are, however, narrow. It seems that cross fertilization will not take place at all, or very rarely, between different species, unless these species are nearly related to each other; and that the offspring of the two distinct species is itself sterile, or if it possesses the power of multiplying itself by seed, its progeny returns back to the state of one or other of its parents." 


\section{INDEX.}

\section{APPLES.}

American Red Juneating

Boxford

Baldwin

Blue Permain

Bellilower

Benoul

Drap D'Or

Duchess of Oldenburg

Danvers Winter sweet

Early Harvest

Early Bough

Early Red Margaret

Fall Harvey

Franklin Golden Pippen

Fameuse

Gravenstein

Golden 'Russet

Green Sweet

Hawthorndean

Hubbardston Nonsuch

Kilham Hill

Kerry Pippen

Lady Apple

Lyscom

Lovett Sweet

Nela Carla

\section{Autumn Superb}

Andrews

Amire Joannet

Beurre D'Aremberg

Beurre Bosc

Beurre, Easter

Beurre, Golden of Bilboa

Beurre Van Marum

Beurre Diel

Bourgmestre, of Boston

Bergamotte D'Automn

Bloodgood

Bon Chretien Fondante

Belle Lucrative

Belle et Bonne

Buffum

Bleeker's Meadow

Black Pear of Worcester

Chair A'Dame

Capsheaf
Page.

59 Minister 62

55 Newtown Spitzenlmurg 58

60 Oslin 50

49 Ortley Pippen 57

48 Porter 51

52 Pennocks 58

60 Pickman Pippen 61

45 Red Ingestrie

46 Rambour D'Ete 47

46 Red Astracan 50

48 Rhode Island Greening 56

53 Ribstone Pippen 54

55 Red Quarenden 55

53 Red Doctor Apple 49

54 Roxbury Russet

63 Summer Queen 46

48 Summer Rose 47

49 Summer Pearmain 47

51 Swaar 60

53 White Winter Calville 58

59 Wine Apple

51 Williams' Favourite Red 49

56 Yellow Ingestrie 52

61

\section{PEARS.}

75 Cabot 81

74 Cumberland 83

64 Crawford 68

95 Citron de Sirentz 69.

80 Cushing 71

95 Catillac 95

80 Dearborn's Seedling 68

76 Dix 88

90 Duchesse D'Angouleme 89

90 Echasserie 94

86 Easter Beurre 95

65 Fig Pear of Naples 91

82 Frederic of Wurtemberg 85

75 Fulton 88

75. Green Pear of Yair 71

79 Gansels Bergamot $\quad .81$

88 GIout Morceau 94

96. Golden Beurre of Bilboa 80

70 Harvard 78

77 Heathcote 78 
PEARS.

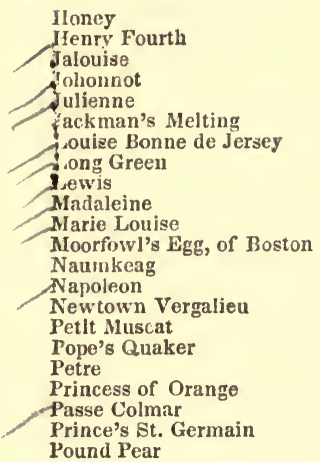

Belle de Vitry

Congress Clingstone

Early Ann

Early Royal George

Grosse Mignonne

Heath Clingstone

Malta

Orange Freestone

Blue Imperatrice

Brevoort's Purple Washington

Bleeker's Gage

Bingliam

Coe's Golden Drop

Cooper's Plum

Duane's Purple

Diamond

Elfrey

Green Gage
Page.

68 Raymond

76 Reine des Poires

73 Rousselette Hatiff

74 Rousselette de Rheims

67 Rostiezer

72 Surpass Vergalieu 77

83 Scckle 73

76 Surpass St. Germain 93

93 Skinless $\quad$ C6

64 Summer Rose $\quad$ C6

87 Summer Franc Real 66

89 Summer Thorn 70

79 St. Ghislain 71

87 Sylvanche Verte 90

91 Urbaniste 85

64. Valee Franche 70

82 Washington 80

81. Williams' Bon Chretien (Bartlett) ' 67

83 Williams' Early 70

92 Wilkinson 86

93 Winter Nelis 92

93

PEACHES.

99 Oldmixon Clingstone $\quad 100$

100 President 99

97 Red Rareripe 97

97 Red Cheek Melacoton. 98

98 Red and Yellow Rareripe 98

101 White Blossom 99

98 White Rareripe 97

100

PLUMS.

107 German Prune $\quad 105$

102 Italian Damask 101

I04 Jtalian Prune 106

106 Kirk's Plum 103

107 Large Long Blue 103

105 Morocco 102

105 Orleans 103

105 Purple Gage 103

105 Prince's Imperial Gage 102

104 Washington 106

\section{CHERRIES.}

108 Gridley $\quad 110$

109 Late Duke 111

110 Napoleon Bigarreau 108

108 Plumstone Morello 112

111 White Bigarreau 110

109 White Mazzard 111

ORNAMENTAL TREES.

Ornamental Trees, Class 1

Onamental Trees, Class 2
113 Ornamental Shrubs, Vines, \&c.

114 Class 3 


\section{ADVERTISING SHEET}

TO THE

\section{BOOK OF FRUITS;}

FOR

1838 . 



\title{
POROZOGICAY GARDHNS,
}

\author{
ON DEARBORN STREET-SALEM.
}

\section{$=$ \\ FRUIT TREES, VINES, SHRUBS, AND \\ ORNAMENTAL TREES.}

Warranted correct, constantly fot sale at ROBERT MANNING'S Pomological Garden, and at JOHN M. IVES' adjoining Nursery-packed for transportation, and at Nursery prices.

SCIONS OF FRUIT TREES, \&c. \&c.

BOOE, STATYOFIR AWD SEED STORE.

\section{IVES \& JEWETT,}

193 ESSEX STREet, have cONSTANTLY FOR SALE,

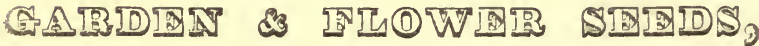

OF THE BEST VARIETIES, DONE UP IN A NEAT MANNER, WITH DIRECTIONS FOR CULTURE, \&C. \&C.

$$
\text { A L S O, }
$$

\section{SCHOOL BOOKS AND STATIONERY,}

\section{WHOLESALE AND RETAIL.}

3.3 All the standard works on AGRICULTURE AND GARDENIJVG together with a complete assortment of CUTLERY-Pruning and Badding Knives, Shears, \&c. \&c. 


\section{AGRICUITURAI WAREFOUSE, SEED STORE,}

AND OFFICE OF THE NEW-ENGLAND FARMER,

No. 31 \& 5 \% North Market Street, BOSTON. JOSEPH BRECK \& CO.

15 THE Proprietors of this Establishment would inform their friends and the public, that they kecp constantly on hand and for sale, the greatest variety of Agricultural Implements, Grass Seeds, Garden and Flower Seeds, Bulbous Roots, Double Dahlias, \&c. \&c. to be found in the country;-among which are the following -

\section{AGRICULTURAL IMPLEMENTS.}

C. Howard's Cast Iron Ploughs,

$\begin{array}{lll}\text { Tice's } & \text { do. do. } \\ \text { Side Hill } & \text { do. } & \text { do. } \\ \text { Double Mould Board } & \text { do. }\end{array}$

Double Mould Board do.

Ploughs,

scott Keith, \& other Plough Castings,

Willis' improved Cultivator,

Green's Patent Straw Cutter,

Willis' do. do.

Common hand do.

Manure and Hay Forks,

Seythes of all kinds,

Patent and other Snaiths,

Hall's and other Hay Rakes,

Grindstones on Rollers,

Corn Shellers, Grain Cradles,

Chains of alt kinds,
Willis' improved Secd Sow

Gault's Patent Churns,

Self Operating Cheese Press,

Horse Yower and Threshing Macline, Davis' Road Scrapers,

Hale's Rotary Pump, Lead Pipe,

Force Pumps, Copper do. Iron do.

Underhill's Cast Steel Axe,

Bark Mills, Corn and Cobb Mills,

Harris' Paint do. Winnowing du.

Grater Cider do.

Cast Iron Cider Screws,

Yokes of all kinds ;

Witl a great variety of Agricultural and Ilorticultural Tools, too numerous to mention.

\section{FIELD SEEDS.}

Northern Clover, Southern do.

White Honeysuckle Clover,

Lucerne, Herds Grass, or Timothy,

Red Top, Southern Seed,

do. Nortliern do.

Fowl Meadow, do.

Orchard Grass, do.

Ruta Baga, Maugel Wurtzcl,

Sugar Beet, \&c.

Winter and summer Wheat, do. do. kye,

Balley, English Oats,

Corn of various sorts, Millet,

Hemp, Flax Seed, Potatoes.

\section{GARDEN SEEDS,}

Of every desirable vanety will be furnished, wholesale and retail, by the pound, box, or packagc. 


\section{SEEDS IN BOXES̃,}

For retailing, done up in the neatest manner in packages, with the name and directions printed on each parcel. Retailers supplied on most favorable terms, with boxes from $\$ 1$ to $\$ 100$.

\section{FOR THE FLOWER GARDEN.}

We have a very extensive collection of choice FLowER SEEDs, embracing alı the Annuals, Bieunials and Perennials worthy of cultivation. Packages of tweuty-five sorts for one dollar.

Dutch Bulbous Roots.-We import of these annually from Holland, a splendid collection, consisting of double and single Hyacinths, double and single 'Tulips, Crown Imperials, Narcissus, Iris, Crocus, Gladiolus, Amaryllis, 1xias, \&c. \&c.

Double Dahlia Roots. - Of this beautiful and popular flower, we have moie than two hundred fine varieties, embracing all that were shown at the exhibition of the Massachusetts Horticultural Society, Roots can be furnished from the first of October to the first of July, safely packed in Moss, and sent to any part of the country.

Fruit and ornamental Trees and Shrubs furnished to order at Nursery prices.

Large plants of the Morus Multicaulis, and cuttings of the same, can be furnished by the hundred or thousand at moderate prices.

We would call the attention of the public to the New-EngLand FArMER; one of the oldest and best agricultural newspapers in the country, containing a great amount of interesting and useful matter for the practical farmer and gardener. It is issued at our office weekly, on Wednesdays, at the moderate price of $\$ 250$ per year in advance, or $\$ 3$ at the close of the year.

We also pnblish the Horticultural Register, and GardenER'S MAGAZINE, issued monthly, at $\$ 2$ per annum in advance, or $\$ 250$ at the expiration of six months. This work is devoted principally to the cultivation of Fruits, Vegetables and Flowers. New subscribers can be supplied with the back volumes at $\$ 250$ per vol. bound.

Among our agricultural Books we keep for sale, The Complete Farmer ; Kenrick's Orchardist ; A merican Gardener; Bridgman's Gardener's Assistant; Moubray on Poultry; Silk Grower's Guide; Cobb's Silk Manual; Loudon's Works, together with a great variety of useful and interesting works in this line.

पT We hope by unremitting attention, to sustain the credit of this Establishment, and realize the anticipations of our predecessors, NzwELL, RusselL, \& BARRETT, in making it one of the most complete depositories for every thing in the Agricultural and Horticultural line in the country. 


\section{BOSTON SEED STORE.}

\section{ELLIS \& BOSSON,}

At their Agricultural Establishment, No. 34, NORTH MARKET STREET, BOSTON, Mass. (up stairs) nearly opposite the centre of the Market, keep constantly on hand, a very great variety of Garden, Grass and Flower Seeds, comprising every kind of vegetable seeds and sioeet pot herbs.

\section{GRASS AND FIFID SFEDS,}

\section{WHOLESALE AND RETAIL.}

'Timothy or Herds Grass,

Northern and Southern Red Top, Northern Clover, Southern do. White Dutcls do.

Luserne, or Freneh Clover,

Orchard Grass, or English Cochfoot, (good for early and late pasturage, ) Millet, White and Brown Mustard, Potatoe Oats, Skinless Oats, Buck Wheat,

Early white Potatoe, best variety, St Helena do

Yellow Locust Seed, for timber trees, Long Blood Beet,

Mangel Wurtzel, for stock,

\section{Ruta Baga,}

Long Orange and Altringham Carrot, White Silesia Sugar Beet,

Black Sea, Gilman, Tea, and Italian Spring Wheat,

Tuscany Wheat, winter, new and fine variety,

Red Chaff, winter,

White Bushy do

Spring and winter Rye,

Broom Corn.

And every kind of seed, early and late, the new as well as the old varieties, on terms very accommodating.

\section{FIOWER SITDS.}

Two hundred very handsome varieties, put up in small papers. Packages containing beautiful Annuals, Biennials and Perennials, at $\$ 1$.

Dutch Bulbous Roots, in great variety.

GARDEN SEEDS will be supplied to traders at wholesale, or at a large discount from retail prices, either by the pound or in boxes, containing a complete assortment, neatly papered and labelled, with printed directions for their culture. These seeds are warranted not only fresh, but of superior quality. Boxes of seeds containing a good assortment for a family garden, at $\$ 3$ per box.

Books upon Agriculture and Rural Economy, wholesale and retail.

TREES, Grape vines, Herbacious, Green House and other Plants in any quantities 


\section{AGRICULTURAL IMPLEMENTS,}

MACHINES, \&C.

Of every kind, and most approved patterns, comprising every thing that is wanted on a FARM, GARUEN, or ORCHARD.

\section{YANKEE FARMER;}

VOLUIIE FOURTH: EDITED BY S. W. COLE, ESQ. ASSISTED BY THE COVTRIBUTIONS OF PRACTICAL FARUERS, AND EXPERIEVCED AGRICULTURISTS.

Ofice, Zio. 34, North Mrarket Street, Boston, Mrass.

The YANKEE FARMER is a weekly publication, of eight pages, devoted to Agriculture, on a large quarto sheet. The price is Two Dolxaks per annum, payable within sixty days from the time of subscribing; and every sixtl copy will be allowed to gentlemen who procure us five subscribers, and remit the money in advance. A volume will contain 416 pages quarto, and be furnished with a copious index and titie page. It is the cheapest agricultural paper in New England, containing more readiug than 2500 pages duidecimo.

Almost every man cultivates a spot of earth, and whether it be a large or small one, he should learn the best productions, the best methods of culture, and the latest improvement in tools and machines. Those who are not cultivators will find much in the Farmer that will be interesting and useful.

Articles on Rural and Domestic Economy, Arts, Trades, Ec. will frequently come home to the business and promote the interest of every reflecting person.

- The Price Current of Country Produce, and a weekly report of the sales at Brigliton Market, will be published in the Farmer.

DS Subscriptions must be sent by mail to

CFARTIS R. BOSSON, Publisher, 34, North Market Street, Boston, Mass. 


\title{
WA RE H DUSE,
}

\author{
No. 9, MERCHANTS' ROW BOSTON.
}

\section{$\operatorname{sen} 90$

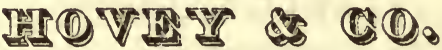 \\ SEEDSMEN AND FLORISTS,}

OFFrR at wholesale and retail, one of the most extensive assortments of GARDEN, GRASS, FIELD, and FLOWER SEED, to be found in New England. Having long been engaged in the cultivation of plants and the raising of seed, they can warrant every article, true to its name and of the best quality.

\section{AGRICUITURAI SIFDS.}

Such as Spring Wheat, Spring Rye, Barley, Buckwheat, Mangel Wurtzel, Ruta Baga, Sugar Beet, Mulberry Seed, Dutton Corn, \&c. \&c. In the selection of these articles, H. \& Co. give the most particular attention, and purchasers may rely upon procuring the most approved kinds, and of genuine quality.

\section{CRASS SEgDS.}

Herds Grass, Red Top, Northern and Southern Clover, White Dutch Clover, Lucerne, Orchard, Rye, and Dew Grass, Millet, \&c. at wholesale and retail.

\section{GARDEN SFFDS.}

The great variety of vegetable seeds renders it impossible to enumerate them in an advertisement. In addition to all the old and approved kinds, they annually receive from the first seedsmen in Europe, every thing that is new or rare. The following are among those of more recent introduction :-

Cedo Nulli Peas (early)

Groone's Superb Dwarf Blue

Early Warwick Peas
Bailey's Giant Red Celery

do do White do

Early Vanack Cabbage 


\section{TLOWMR SFIDS.}

400 kinds of Annual and Perennial FLOWER SEEDS, embracing all the most choice and beautiful;

12 varieties of Superb Donble German Asters;

10 do. of double dwarf Larkspurs;

6 do. of Zumiss, \&c. \&c. all raised by themselves, and warranted to be the most beautiful in cultivation.

Packages of 20 kinds handsomely put up for $\$ 1$.

100 elegant varieties in one package, $\$ 4$.

\section{GRIFATOUSE PTANTS,}

Including 200 varieties of Camellias ; 40 of Erica's or Heaths, Azaleas, Rhododendrons, Geraniums, \&c. ; Hardy Perennial Flowering Plants, \&c.

A large collection of the most splendid DAHLIAS, Bulbous Flower Roots, \&c. \&.c.

\section{FRUIT AND ORNATEENTAT TREES,}

Grape Vines, Gopseberries, Strawberries, Asparagus, Rhubarb Roots, \&c.

BOOKS on Gardening, Botany, Agriculture, \&c.

03 DEALERS and others supplied on accommodating terms, with every variety of Garden Seeds, by the pound, bushel, or ounce; or if required, in Boxes, neatly put up in papers, and labelled with the name and all the particulars of cultivation.

पI A liberal discount made from the retail prices.

H. \& CO. publish the MAGAZINE OF HORTICULTURE, volume IV of which cornmenced on Jan. 1, 1838.Nonthly, at \$3 per year.

Catalogurs may be had on application.

* * Orders for any kind of Seeds, Plants, or 'Trees, directed to JOVEY \&. Co. No. 9, Merchants' Rovo, Boston, will meet with prompt attention, and be faithfully executed,-Plants packed so as to go safely to any part of the country. 


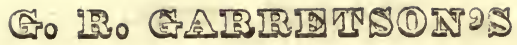

WHOLESALE AND RETAIL

\section{AGIICUITURAIATDGARDEM SIED WAREDOUE,}

FLUSHING L. I. NEW YORK.

ALWAYS ON HAND, A LARGE ASSORTMENT OF

AGRICUltural, KITCHEN GARDEN AND FLOWER

\section{S: $\mathbf{D} \mathbf{D} \mathbf{D}$,}

of the greatest variety, and at reduced prices.

ALso,

A large collection of the most superb varieties of DaHLis.

Morus Multicaulis Plants can be supplied in any quantities, \& at moderate rates.

In fact every thing appertaining to the Seed or Nursery business can be supplied; and to those who purchase to sell again, a liberal deduction will be made.

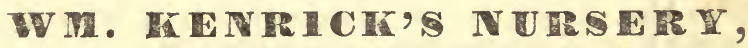

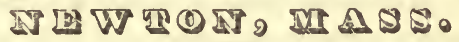

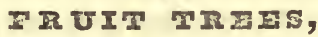

A MOST EXTENSIVE VARIETY OF THE FINEST SORTS, INCLUDING THE CELEBRATED

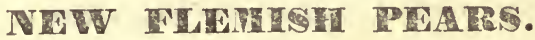

Arso-A pples, Cherries, Peaches, Plums, Nectarines, Apricots, Almonds, Quinces, Grape Vines, Currants, Raspberries, Fine imported Lancashire Gooseberries.

MULBERRIES FOR SILK, at a liberal discount, by the hundred or thousand, including the Clinese, or Morus Multicaulis.

05 All orders left with IVES \& JEWETT, at their Book and Seed Store, 193 Essex Street, will be duly attended to.

C.ATALOGUES gratis, on application. 


\title{
AGRICULTUIRAT WRETOESE.
}

\author{
WILLIAM H. CHASE, \\ AT THE CHAMBERS OVER HIS HARD-WARE STORE, 186 ESSEX \\ OPPOSITE CENTRAL STREET,
}

HAS CONSTANTLY ON HAND,

AN ASSORTMENT OF

\section{AGRIOULTURAI IMPIEMIENT,}

C Howard's Cast Iron Ploughs J. \& J. Sylvester's do do Plough Castings,

Corn Shellers

Willis' Improved Seed Sower, Green's Patent Straw Cutter, Willis' Common hand Lead Pipe,

Cast Iron Pumps, Copper do Wood do Gault's Patent Churns, Shaker and common Churns,
Manure and Hay Forks, Farwell's Scythes Colby's do Patent and common Snaiths, Wilder and Eddy's Rakes, Grindstone Rollers Corn Mills, Paint do Cast Steel Shovels, Iron do Garden Tonls of all kinds. Cast Iron Boilers, Cast Steel Hoes,

\section{THRDSHING IMAOHINIS,}

Together with a great variety of other Agricultural and Horticultural TOOLS, which will be sold on the most favorable terms.

Any description of AGRICULTURAL IMPLEMENTS that may be wanted, will be proeured at short notice from the manafacturers.

SALem, 3d movth, 5th, 1838. 



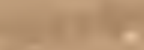

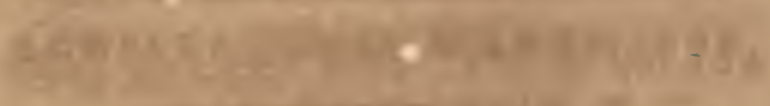

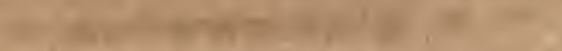

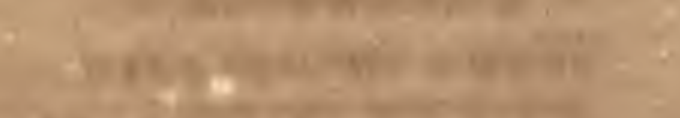

$-$

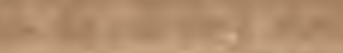

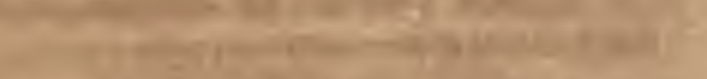

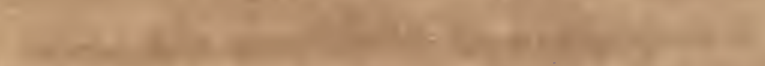

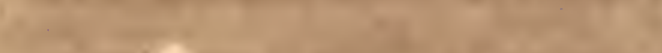

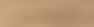
-

$+$

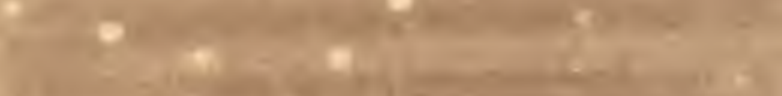

\section{4}

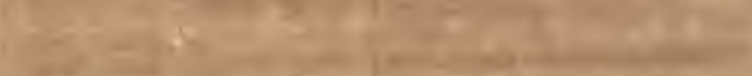

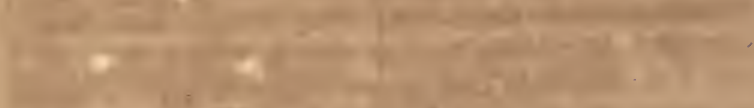

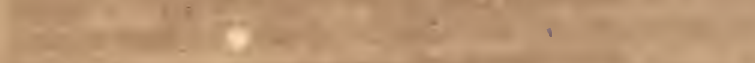
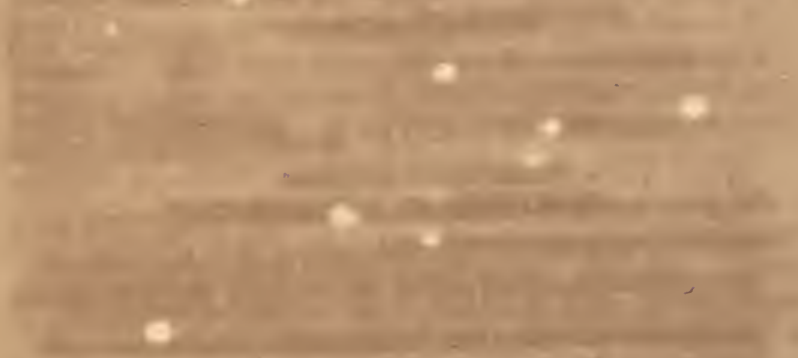

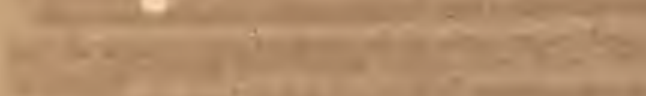

and

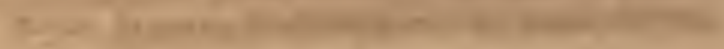

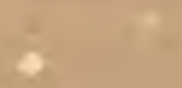

8

요

$+8$ 

(n) 10

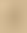

-

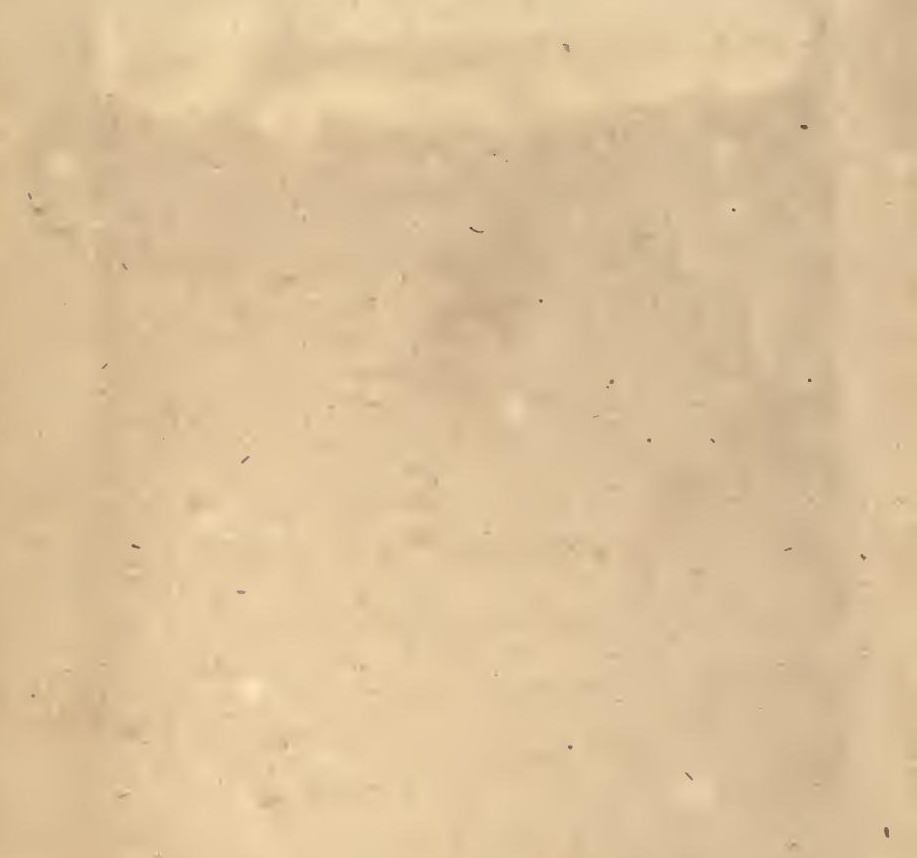


UNIVERSITY OF CALIFORNIA

BRANCH OF THE COLLEGE OF AGRICULTURE

THIS BOOK IS DUE ON THE LAST DATE STAMPED BELOW 
Mannins, Robert 30ok of fruits.

\section{$S B 355$ M29}

6999

LIBRARY, BRANCH OF THE COLLEGE OF AGRICULTURE 


$$
\text { (n) }
$$$$
\text { * }
$$$$
\text { xy }
$$

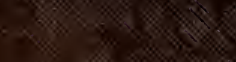$$
\text { (2) }
$$$$
\text { (x) }
$$

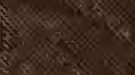

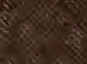

and

m

\section{(2)}

